$$
\begin{aligned}
& \text { s) } \\
& 533 \\
& \text { A42 }
\end{aligned}
$$

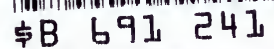$$
1922
$$ 

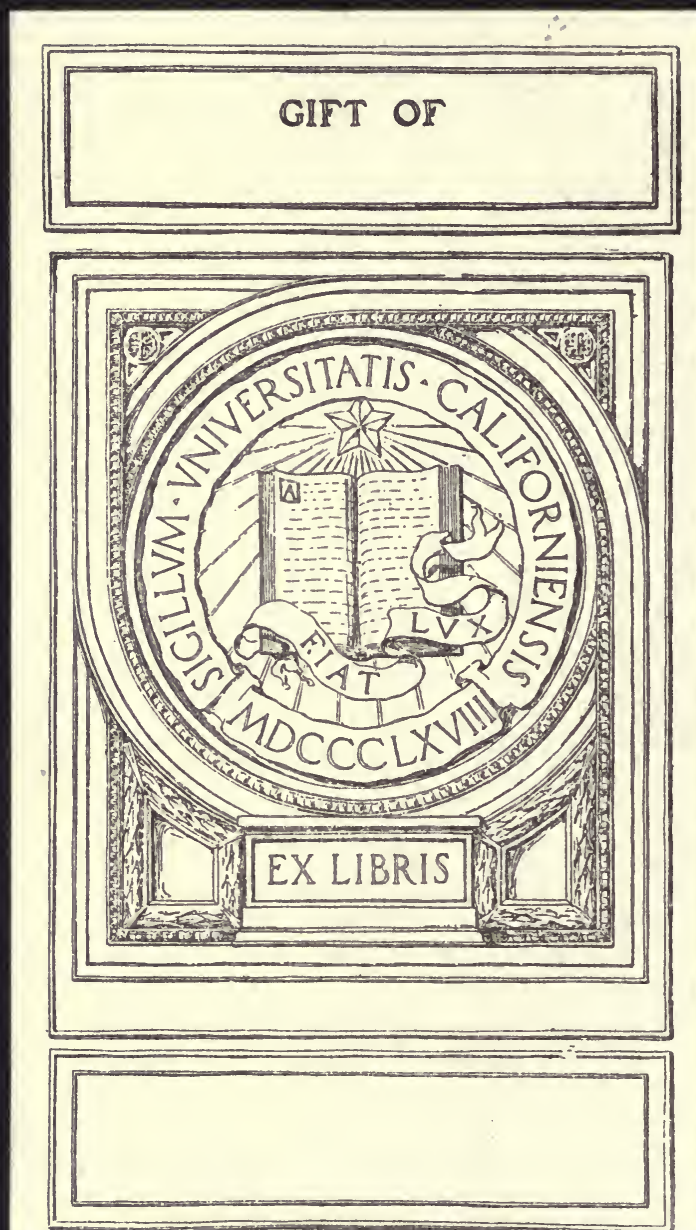


\section{DEPARTMENT OF AGRICULTURE}

\section{EDUCATION AND RESEARCH IN AGRICULTURE AND HOME ECONOMICS IN THE UNITED STATES}

REPORT PREPARED FOR

THE COMMISSION OF THE UNITED STATES OF AMERICA TO THE BRAZIL CENTENNIAL EXPOSITION

Por Distribution at the Brazil Centennial Exposition 1922-1923 


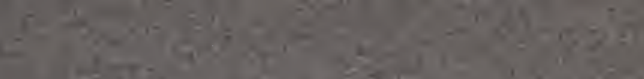

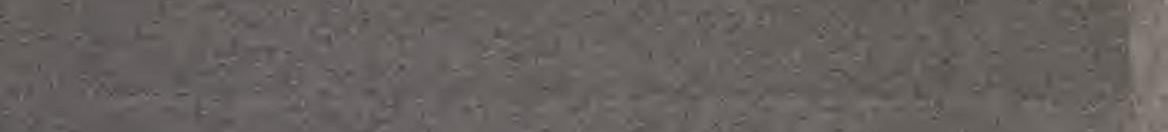

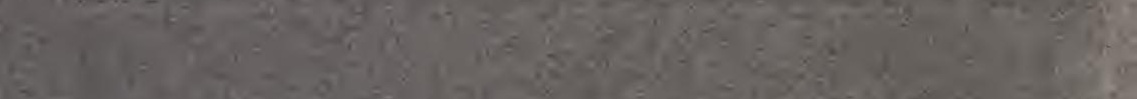

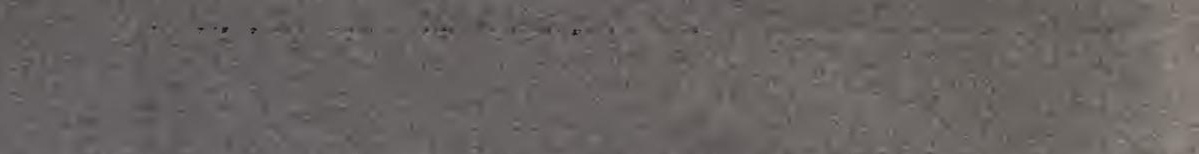

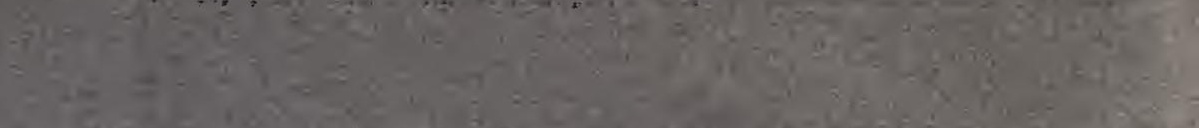

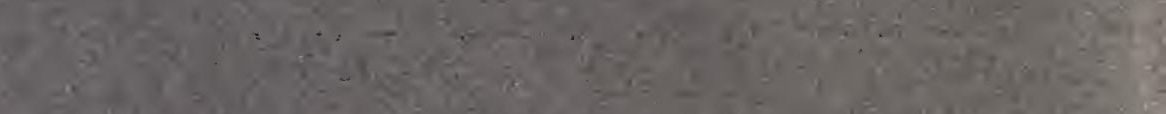

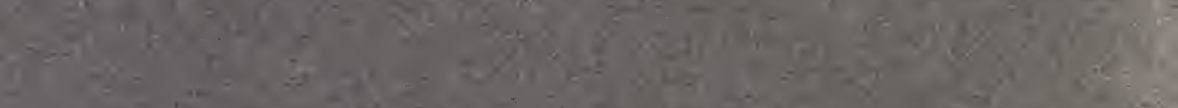

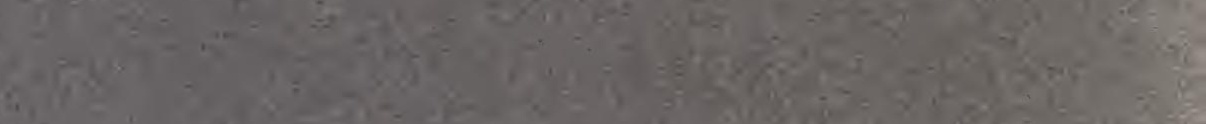

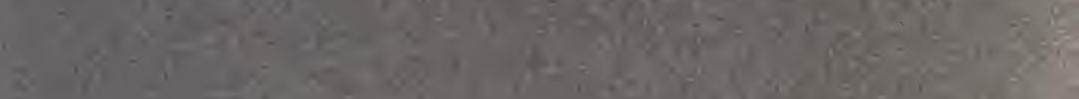

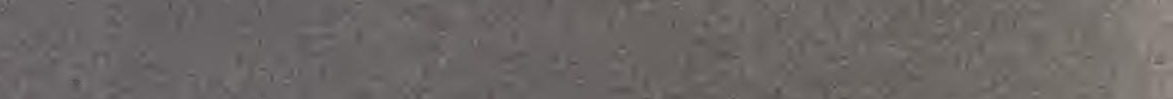

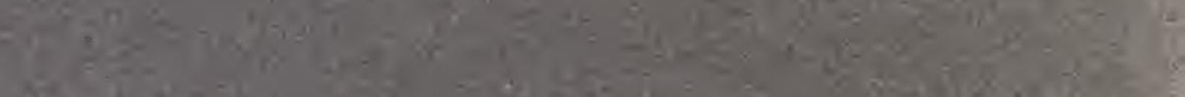

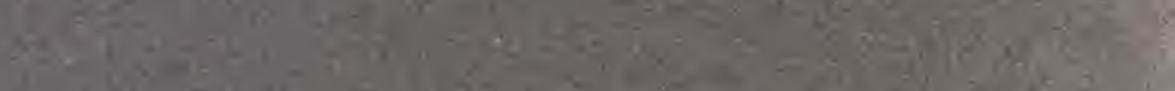

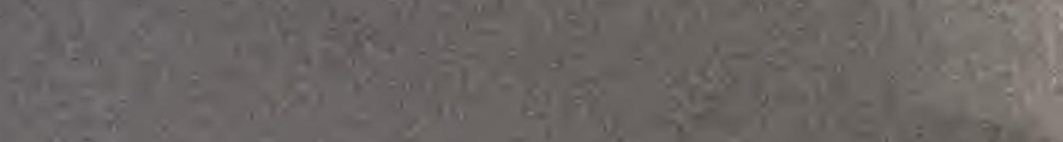

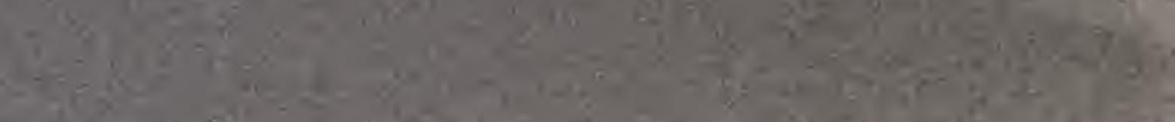

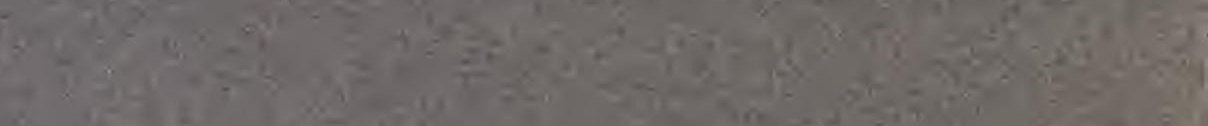
W.

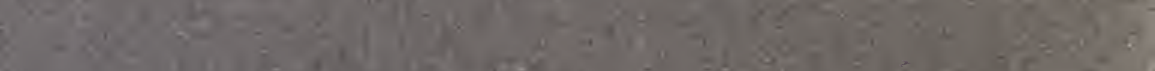
S.

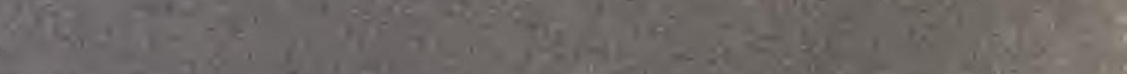
W.

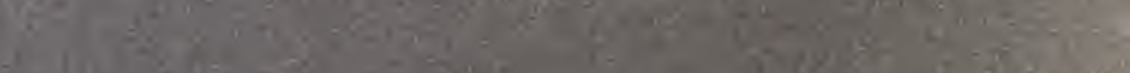

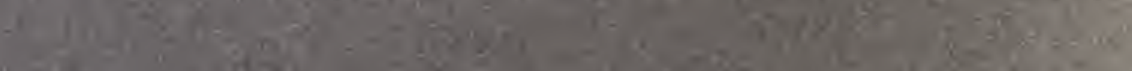

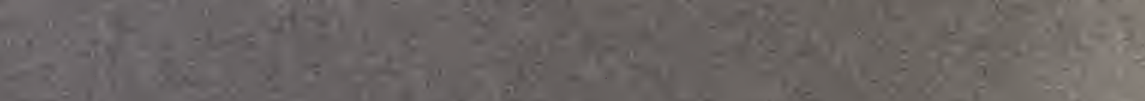

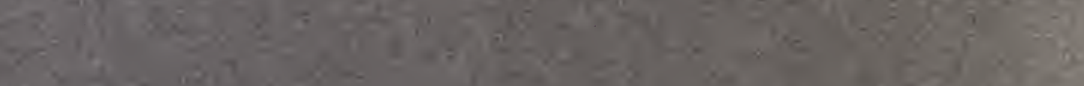
-

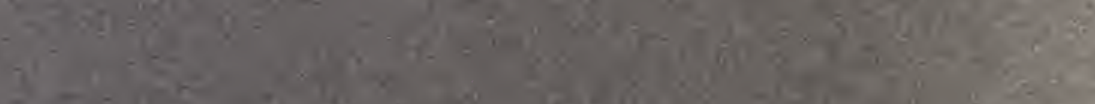

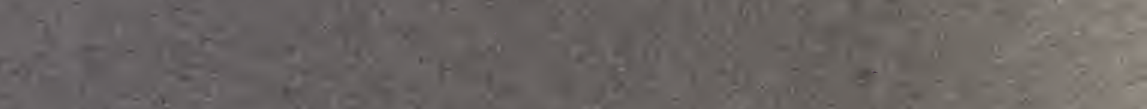

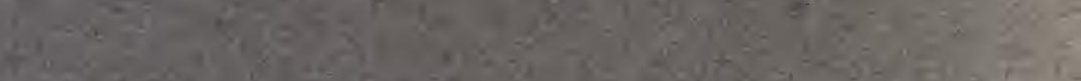

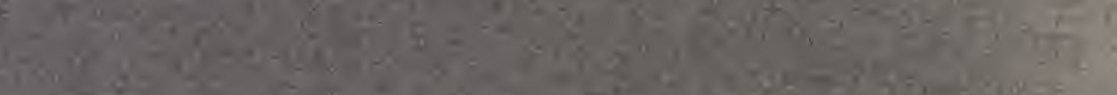

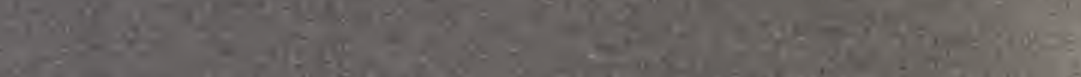

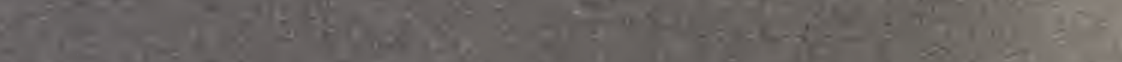

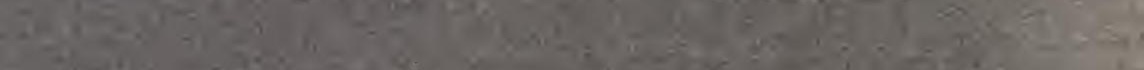

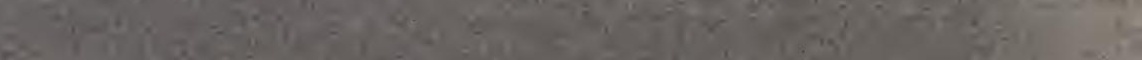

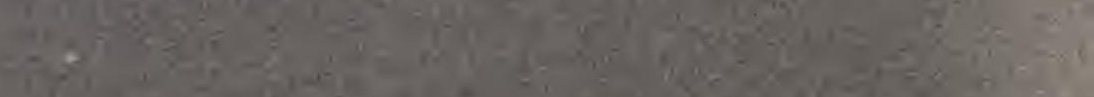




\title{
EDUCATION AND RESEARCH IN AGRICULTURE AND HOME ECONOMICS IN THE UNITED STATES
}

\author{
$\nabla$ \\ Supplementing Exhibit \\ of the \\ STATES RELATIONS SERVICE \\ UNITED STATES DEPARTMENT OF AGRICULTURE \\ at the \\ BRAZIL CENTENNIAL EXPOSITION \\ - Rio de Janeiro, Brazil \\ 1922-1923
}

By

A. C. TRUE

Director

States Relations Service 


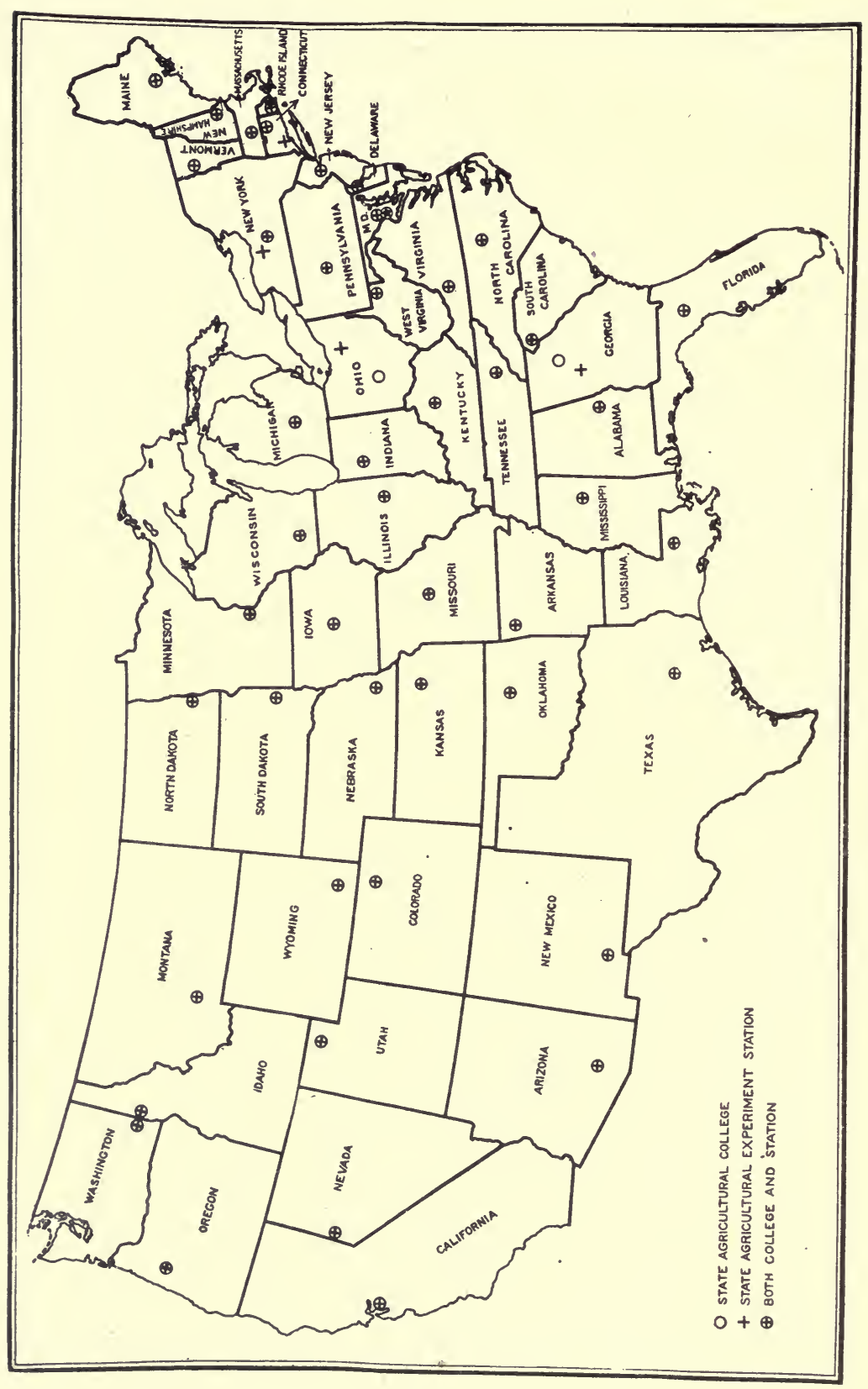

ป⿱艹 


\section{INDEX.}

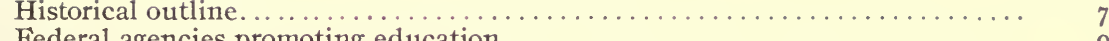

Federal agencies promoting education.................................. 9

Agencies for research in agriculture and home economics.............. 9

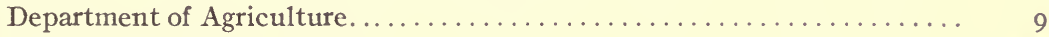

Office of Experiment Stations.......................... II

Agricultural experiment stations............................ I2

Higher education in agriculture ........................... I7

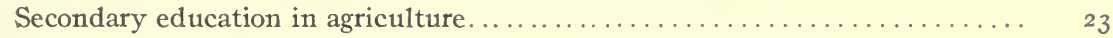

Elementary education in agriculture.......................... ${ }_{2} 6$

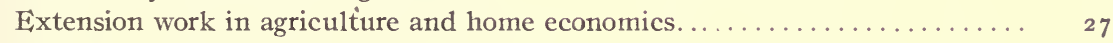

Elementary education in home economics.........................

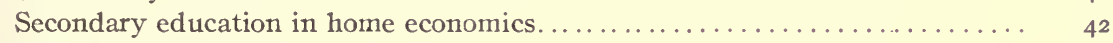

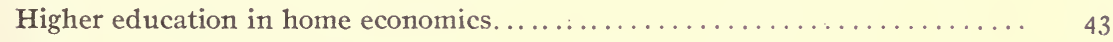

Research in home economics................................ 43 


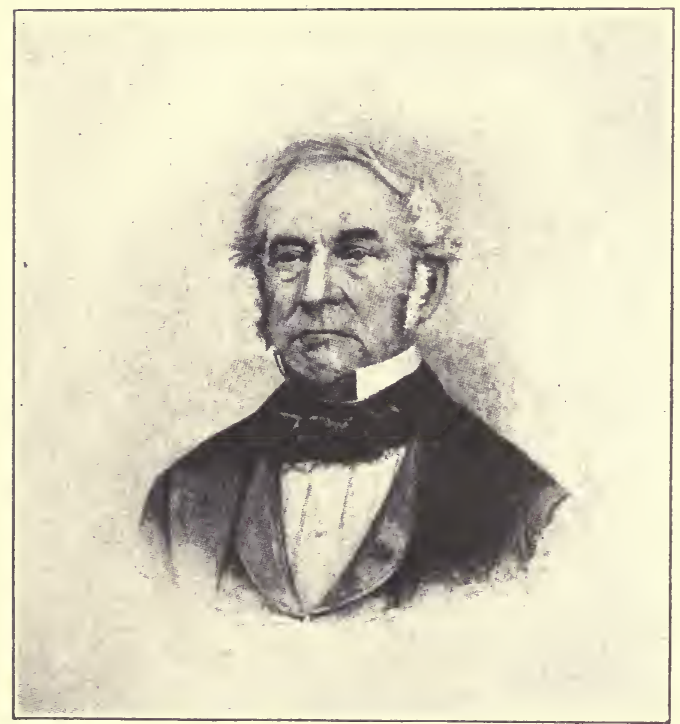

Fig. 2.-Henry L. Ellsworth, founder of the United States Department of Agriculture. 


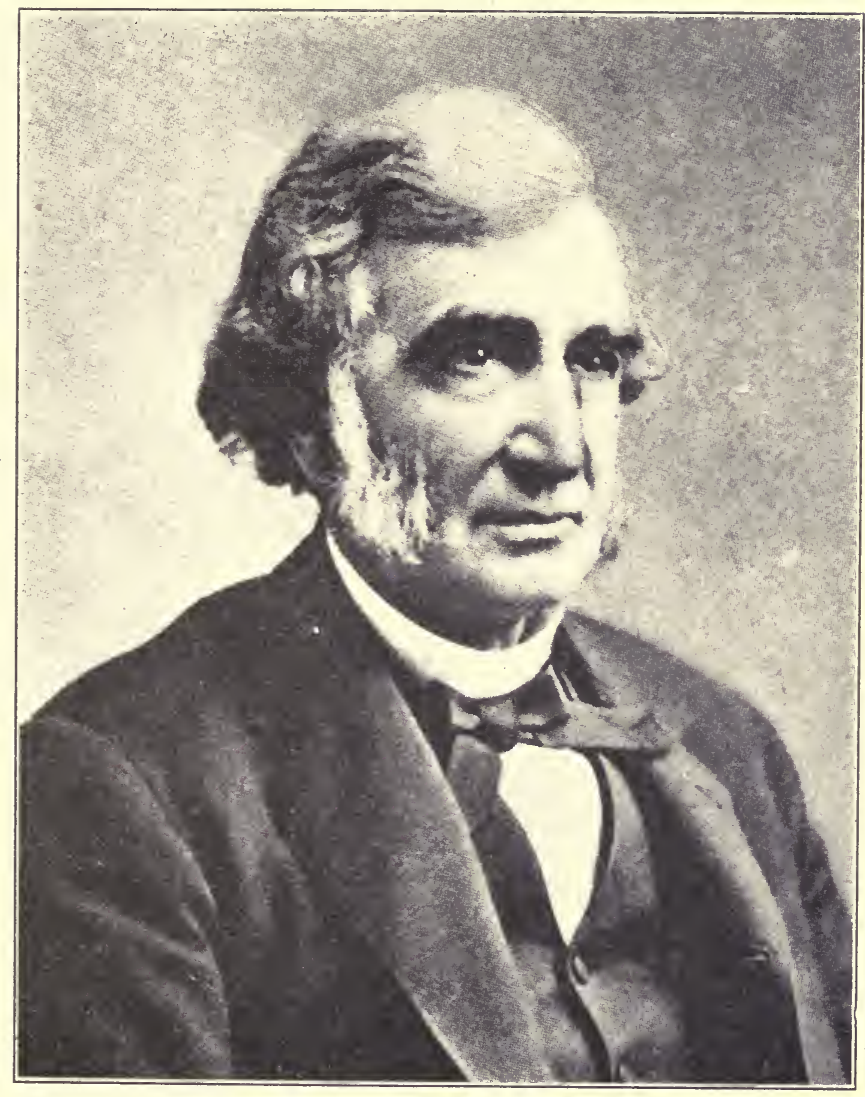

Frg. 3.-Justin S. Morrill, author of the act establishing the land-grant colleges. 


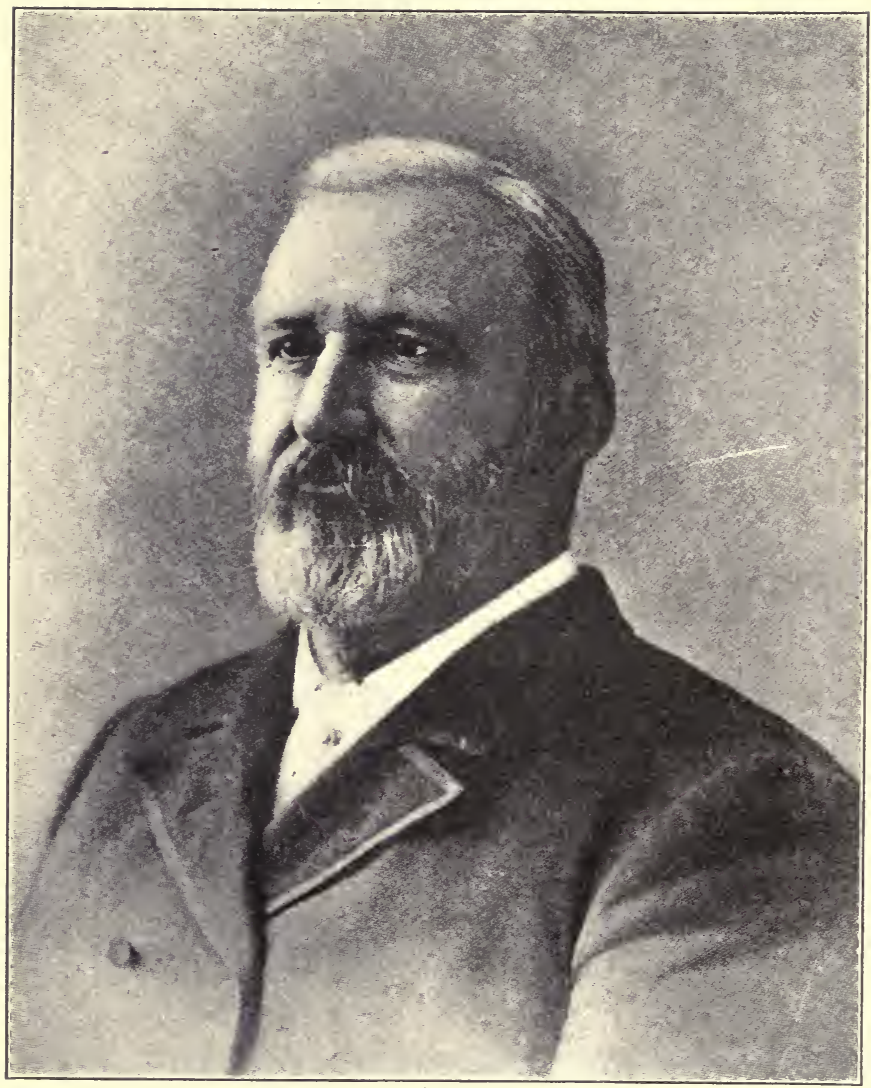

FIG. 4.-William H. Hatch, author of the act establishing the State agricultural experiment stations. 


\section{EDUCATION AND RESEARCH IN AGRICULTURE AND HOME ECONOMICS IN THE UNITED STATES.}

In the United States education is chiefly maintained and controlled by the States, counties, municipalities, and townships. The Federal Government has charge of education only in the District of Columbia, Indian reservations, Alaska, and some of the insular possessions. It has, however, made grants of land and money to the States for the partial support of colleges and secondary schools in which agriculture, home economics, and other vocational subjects are taught and for agricultural experiment stations. Research in agriculture and home economics is also carried on by the United States Department of Agriculture.

\section{HISTORICAL OUTLINE.}

Efforts to disseminate information regarding improved methods of agriculture and to apply scientific principles to agricultural practices were begun in the United States in the closing years of the eighteenth century through the formation of agricultural societies. During the first half of the nineteenth century agriculture was taught in a number of schools. Attempts were also made to create colleges in which the sciences and their applications to agriculture and other industries would be taught. In 1857 the first State agricultural college was opened to students at Lansing, Mich. This movement was greatly broadened by the passage in 1862 of the land-grant act of Congress under which large tracts of land were given to the States, from the sale of which permanent funds were established for the endowment of colleges "where the leading object shall be, without excluding other scientific and classical subjects, and including military tactics, to teach such branches of learning as are related to agriculture and the mechanic arts, $* * *$ in order to promote the liberal and practical education of the industrial classes in the several pursuits and professions in life."

Under this act and supplementary legislation colleges in which agriculture was taught were established in all the States. In 20 States these institutions have developed into State universities in which there are colleges of agriculture. In 1890 Congress passed the so-called Morrill Act, granting Federal funds to the States for these colleges. This was supplemented in 1907 by the Nelson amendment, granting additional funds.

Under these two acts each State received $\$ 50,000$ annually. In 17 Southern States this money is divided between colleges for the white 
and colored races. The States have liberally supported the land-grant institutions, and at present the Federal funds constitute only a small part of their current revenues.

In 1839 the Federal Government, through the Patent Office, began the collection and distribution of seeds of economic plants. This was soon supplemented by studies and publications on agricultural subjects. In 1862 a Department of Agriculture was established, and in 1889 this became a department of Cabinet rank, having at its head a Secretary of Agriculture. Scientific research related to agriculture has been greatly developed in this department, particularly since the beginning of the present century, and it is now the greatest organization for this purpose in the world. Research in the field of home economics has also been carried on in this department since 1894 .

The first agricultural experiment station was established in Connecticut in 1875 . Other States very soon followed this example.

In 1887 Congress passed the Hatch Act for the maintenance in all. the States of agricultural experiment stations, which, with few exceptions, are departments of the agricultural colleges. This was supplemented in 1906 by the Adams Act. Under these acts each State receives $\$ 30,000$ annually. The stations also receive State and other funds greatly in excess of the Federal funds.

In 1914 Congress passed the Smith-Lever Agricultural Extension Act, which provides for extension work in agriculture and home economics to be carried on by the State agricultural colleges in cooperation with the United States Department of Agriculture. The act grants to the United States considerable amounts of Federal funds which are to be mainly offset by funds from sources within the States.

Meanwhile the teaching of agriculture had spread from the colleges to many secondary schools and a considerable number of elementary schools.

During the second half of the nineteenth century the teaching of cooking and sewing was introduced into many elementary schools. Broader courses in these and other subjects in the field of home economics were given in the secondary schools. The teaching of home economics was, however, chiefly confined to city schools but has recently spread to a considerable number of rural schools. To supply teachers of home economics, a number of State and private colleges and normal schools undertook to give courses in which the teaching of household practices was combined with instruction in the natural sciences and their application to household arts and family life.

The instruction in agriculture and home economics in schools and colleges is a part of a broader movement for education relating definitely to the various vocations pursued in modern communities. Technical and vocational schools and courses have greatly multiplied in recent.years. 


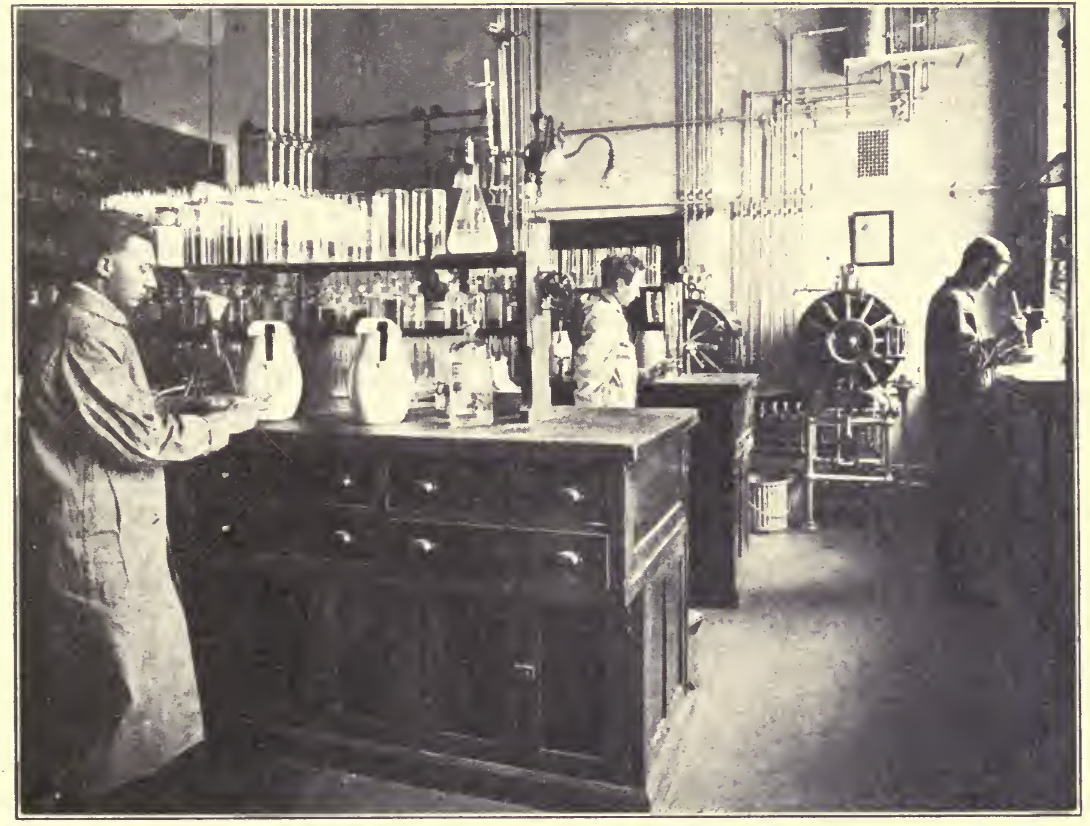

FIG. 5.-One of the laboratories of the United States Department of Agriculture. $27815-23-2$ 
To further promote vocational education throughout the United States, Congress passed in 1917 the Smith-Hughes Vocational Education Act, under which Federal funds, offset by State funds, are provided for secondary instruction in agriculture, home economics, trades, and other industries and for the training of teachers of these subjects.

\section{FEDERAL AGENCIES PROMOTING EDUCATION.}

The Bureau of Education of the Department of the Interior promotes education in a broad way throughout the United States by the collection and dissemination of statistical and other information regarding the organization and work of universities, colleges, and schools in this and other countries. It has the administration of the Federal acts granting funds to the State land-grant colleges and has charge of the public schools in Alaska. Its publications contain considerable information regarding education in agriculture and home economics.

The Federal Board for Vocational Education administers the Federal vocational education act (Smith-Hughes Act) and studies and reports on the problems of vocational education in agriculture, home economics, trades, and other industries.

The United States Department of Agriculture, besides administering the Smith-Lever Extension Act and cooperating with the State agricultural colleges in carrying on extension work in agriculture and home economics, has a division in the States Relations Service which prepares subject matter and illustrative material in form for the immediate uses of teachers in schools where agriculture is taught. It cooperates with the Bureau of Education, Federal Board for Vocational Education, State departments of education, and agricultural colleges in studying the problems of agricultural education and the preparation of agricultural courses for secondary and elementary schools.

AGENCIES FOR RESEARCH IN AGRICULTURE AND HOME.ECONOMICS.

The principal agencies for research in agriculture and home economics are the United States Department of Agriculture and the State agricultural experiment stations.

DEPARTMENT OF AGRICULTURE.

The Department of Agriculture, under the act of Congress of 1862 establishing it, has authority "to acquire and to diffuse among the people of the United States useful information on subjects connected with agriculture in the most general and comprehensive -sense of that word." Subsequent laws have enlarged its functions by establishing within it regulatory and service agencies, some of which have duties outside the agricultural field. In 1889 the department was raised to the first rank, having at its head a member of the President's Cabinet. 
Since that time its growth has been great and rapid. At present its general officers are the Secretary of Agriculture, Assistant Secretary (in charge of extension work, publications, and exhibits), and Director of Scientific Work. Its employees number 20,000 , of whom 4,800 are in Washington. About 2,000 scientists are engaged in its research work. In $192 \mathrm{I}-22$ the appropriations for its regular work and publications aggregated $\$ 40,000,000$, of which $\$ 10,000,000$ is used for research.

Its research work is done through the following bureaus: Weather Bureau, Bureau of Animal Industry, Bureau of Plant Industry, Forest Service, Bureau of Soils, Bureau' of Chemistry, Bureau of Entomology, Bureau of Biological Survey, Bureau of Public Roads (and agricultural engineering), Bureau of Agricultural Economics, and States Relations Service (including Office of Experiment Stations, Division of Insular Stations, and Office of Home Economics). There are also a Division of Publications and an Office of Exhibits. Besides a large number of scientific and technical reports and bulletins and popular publications, especially the series of farmers' bulletins, the department publishes the following periodicals: Journal of Agricultural Research, Experiment Station Record, and Weather Review.

The research work is carried on in laboratories and experimental fields in Washington and vicinity and at field stations in the States, Alaska, and the insular possessions. There are also many special investigations in the United States and other countries and much research work in cooperation with the State agricultural colleges and experiment stations.

OFFICE OF EXPERIMENT STATIONS.

The Office of Experiment Stations in the States Relations Service administers the Federal acts (Hatch and Adams Acts) granting funds to the State agricultural experiment stations, makes an annual inspection of their work and expenditures under the Federal acts, has advisory relations with them regarding lines of work, equipment and personnel, prepares reports to Congress on their work and expenditures, collects and disseminates information regarding similar institutions throughout the world.

The Experiment Station Record, prepared in this office, contains summaries of the publications of the Department of Agriculture and the agricultural experiment stations and similar institutions in the United States and elsewhere and of other scientific literature pertaining to agriculture wherever published, together with editorials and notes on developments in agricultural research and the progress of institutions for agricultural education and research throughout the world. The Record is published in two annual volumes of nine numbers each, with detailed author and subject index. The forty-seventh volume is now in progress. 
Agricultural experiment stations have been established under Federal and State laws in 48 States. There are 50 of these stations, 47 of which are departments of agricultural colleges. In Ohio the station is a separate institution. In New York, Connecticut, and New Jersey there are separate stations, in addition to those connected with the colleges. In a number of the larger States substations are maintained under State laws. These are mainly engaged in the more practical experiments with crops and live stock to meet special local conditions.

In 192 I the total income of the stations was about $\$ 7,500,000$, of which $\$ \mathrm{I}, 440,000$ were Federal funds granted under the Hatch and Adams Acts (\$30,000 to each State), about $\$ 3,700$,000 were State funds, $\$ 1,000,000$ were proceeds of sales of farm products, and about $\$ 1,360,000$ came from miscellaneous sources.

The general management of the stations is given by the State legislatures to boards of trustees, which generally are also the boards managing the agricultural colleges. Usually the members of these boards are appointed by the governors of the States, but in some States they are elected by the people. The trustees determine the general policy of the stations, pass in a general way on its equipment, work, and expenditures, and appoint its principal officers.

Governors, State superintendents of education, or commissioners of agriculture are in some States ex officio members of the station board.

The direct management of the station is committed to a director, who reports to the president or dean of the college.

The staff consists of scientists and technically trained persons representing different branches of agricultural science and practice. There are also farm superintendents, clerks, laborers, and other helpers.

About $\mathrm{I}, 900$ persons are employed in the work of the station, of whom more than 1,500 are scientists and technically trained persons. About 500 of these give part of their time to teaching or extension work.

The stations are partly housed in buildings used also by the teaching and extension departments of the colleges and also use portions of the college farms, which often comprise hundreds of acres. But they also have many special buildings, experimental fields, farm machinery, animals, and elaborate equipment devoted entirely to research.

In the Hatch Act, which grants $\$ 15,000$ to each State, the work of the stations is defined as follows:

It shall be the object and duty of said experiment stations to conduct original researches or verify experiments on the physiology of plants and animals; the diseases to which they are severally subject, with the remedies for the same; the chemical composition of useful plants at their different stages of growth; the comparative advantages of rotative cropping as pursued under the varying series of crops; the capacity of new plants or trees for acclimation; the analysis of soils and water; the chemical composition of manures, natural and artificial, with experiments designed to test the 
comparative effects on crops of different kinds; the adaptation and value of grasses and forage plants; the composition and digestibility of the different kinds of food for domestic animals; the scientific and economic questions involved in the production of butter and cheese; and such other researches or experiments bearing directly on the agricultural industry of the United States as may in each case be deemed advisable, having due regard to the varying conditions and needs of the respective States and Territories.

Under the Adams Act, which grants $\$$ I5, 000 to each State, the work must be confined to original research. The funds provided under this act are therefore used for the more fundamental scientific work of the stations. For a considerable period the work of the stations was chiefly on problems relating to plant and animal production. In recent years increasing attention has been given to studies connected with cost of production, marketing, standardization of products, and other economic problems.

In addition to their experimental work, many of the stations have carried on analytical and other work connected with State control of fertilizers, food, feeding stuffs, seeds, diseases of plants and animals, etc. The present tendency is to lodge such work more fully in the State departments of agriculture.

The headquarters of the stations are as a rule at the agricultural colleges, where the more important work in laboratories, greenhouses, barns, and fields is carried on. There are, however, many special investigations and experiments in different localities, including a considerable number of experiments in cooperation with farmers.

The results of the station work are disseminated through annual reports and popular and scientific bulletins, which are transmitted in the mails free of charge for postage. In I92 I the stations issued 400 publications and their mailing lists aggregated $\mathrm{x}, 000,000$ addresses. Summaries of these publications and other information regarding the stations are also widely circulated through the agricultural and other journals. Station officers, State and county extension agents, and cooperating farmers give information and demonstrations to large numbers of farming people at meetings, through correspondence, telephone messages, visits to farms, and in other ways.

\section{HIGHER EDUCATION IN AGRICULTURE.}

The institutions for higher education in agriculture are of two types: (I) Colleges of agriculture in universities, and (2) separate colleges in which instruction in agriculture is combined with instruction in mechanic arts, home economics, and a variety of other subjects. The courses in agriculture in these two types of institutions do not vary materially. Their number and range depend chiefly on the income, equipment, and size of the agricultural faculty. College courses in agriculture are given chiefly in the public land-grant colleges and universities, but a number of private institutions also offer such courses. 
I4 AGRICULTURE AND HOME ECONOMICS IN UNITED STATES.

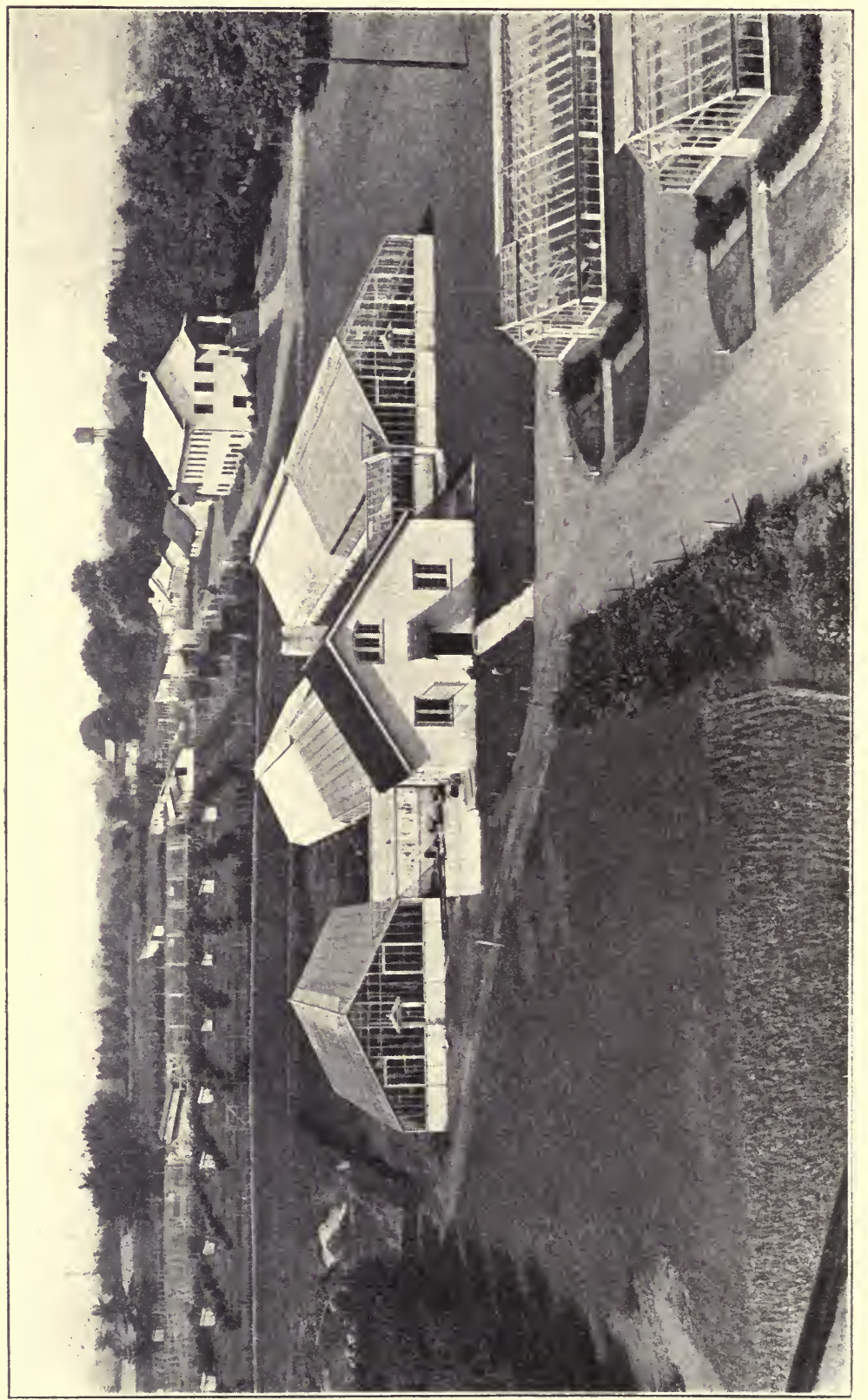

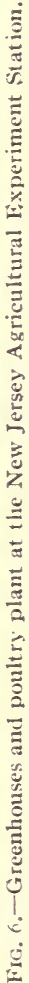




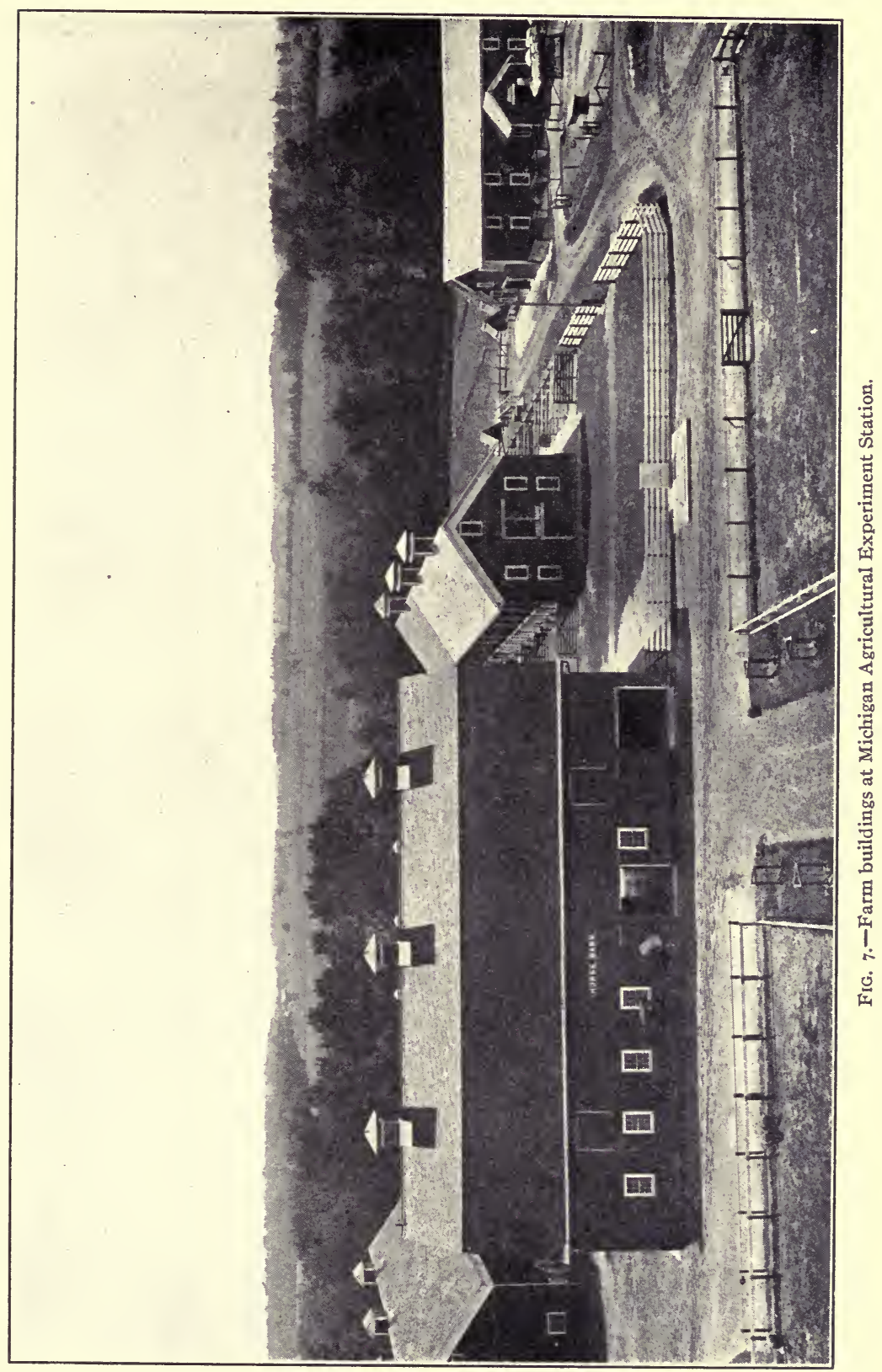


I6 AGRICULTURE AND HOME ECONOMICS IN UNITED STATES.

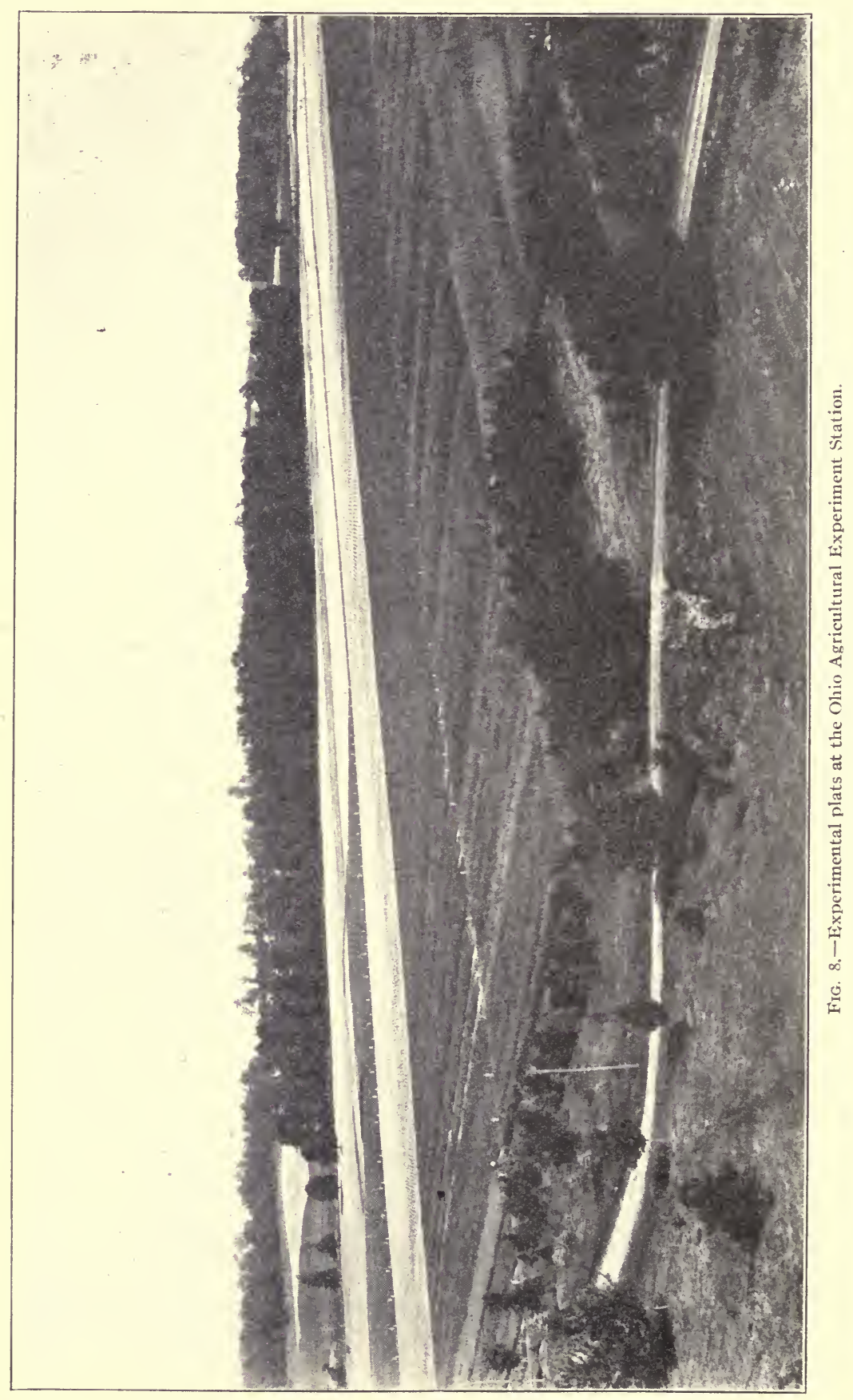




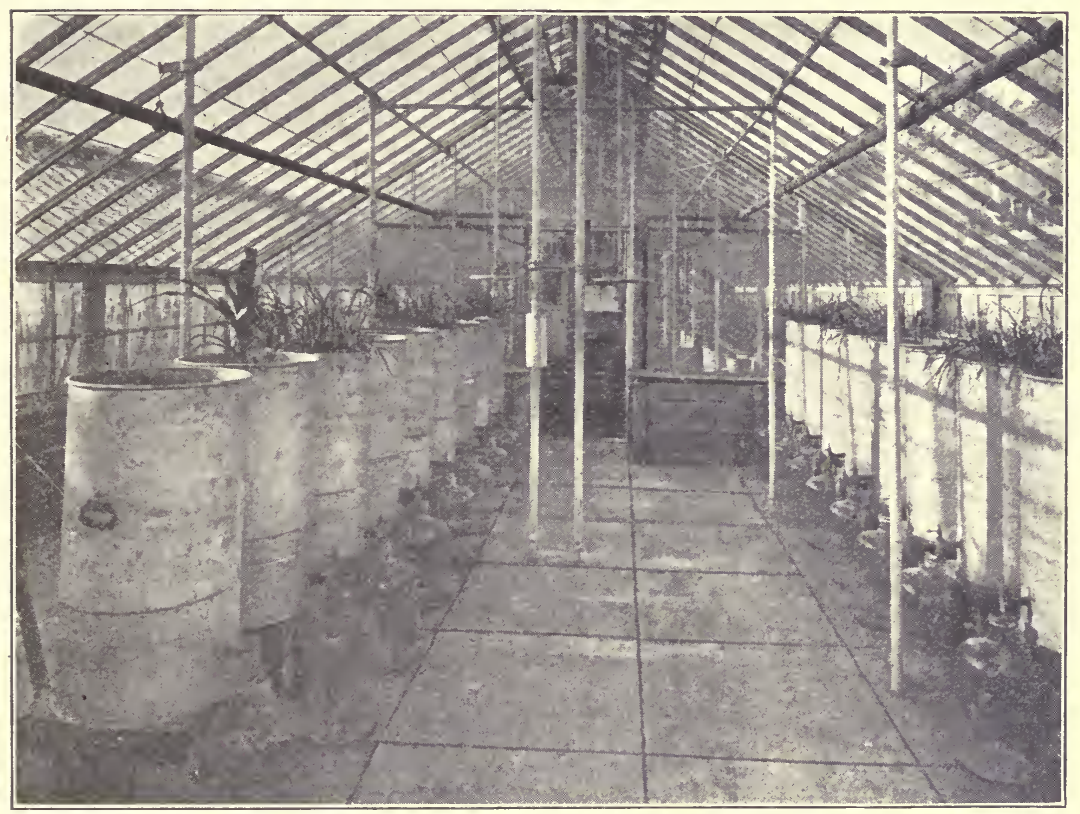

Frg. 9.-Soil studies at the New York Cornell Agricultural Experiment Station. $27815-23-3$ 


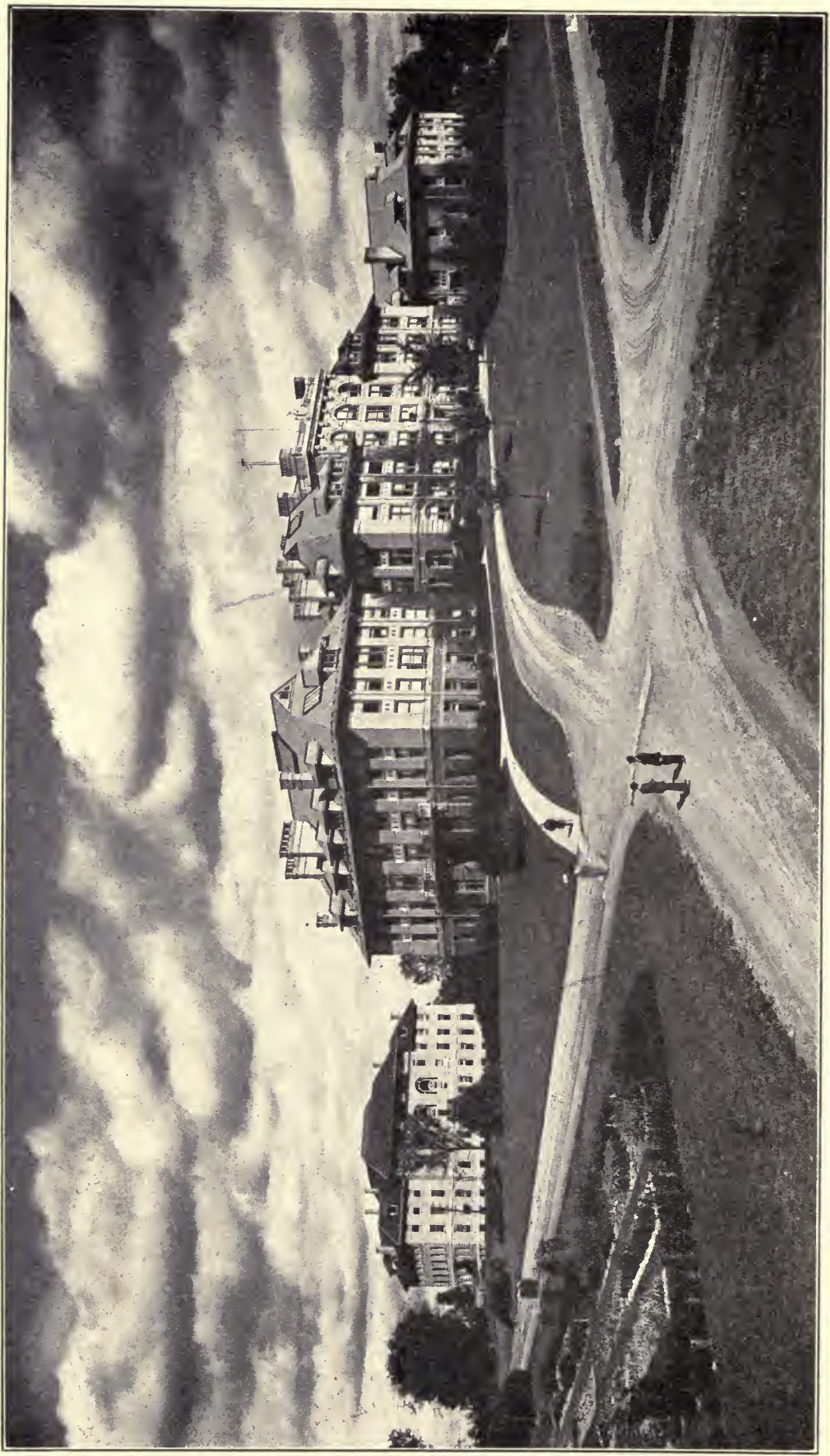

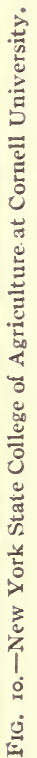




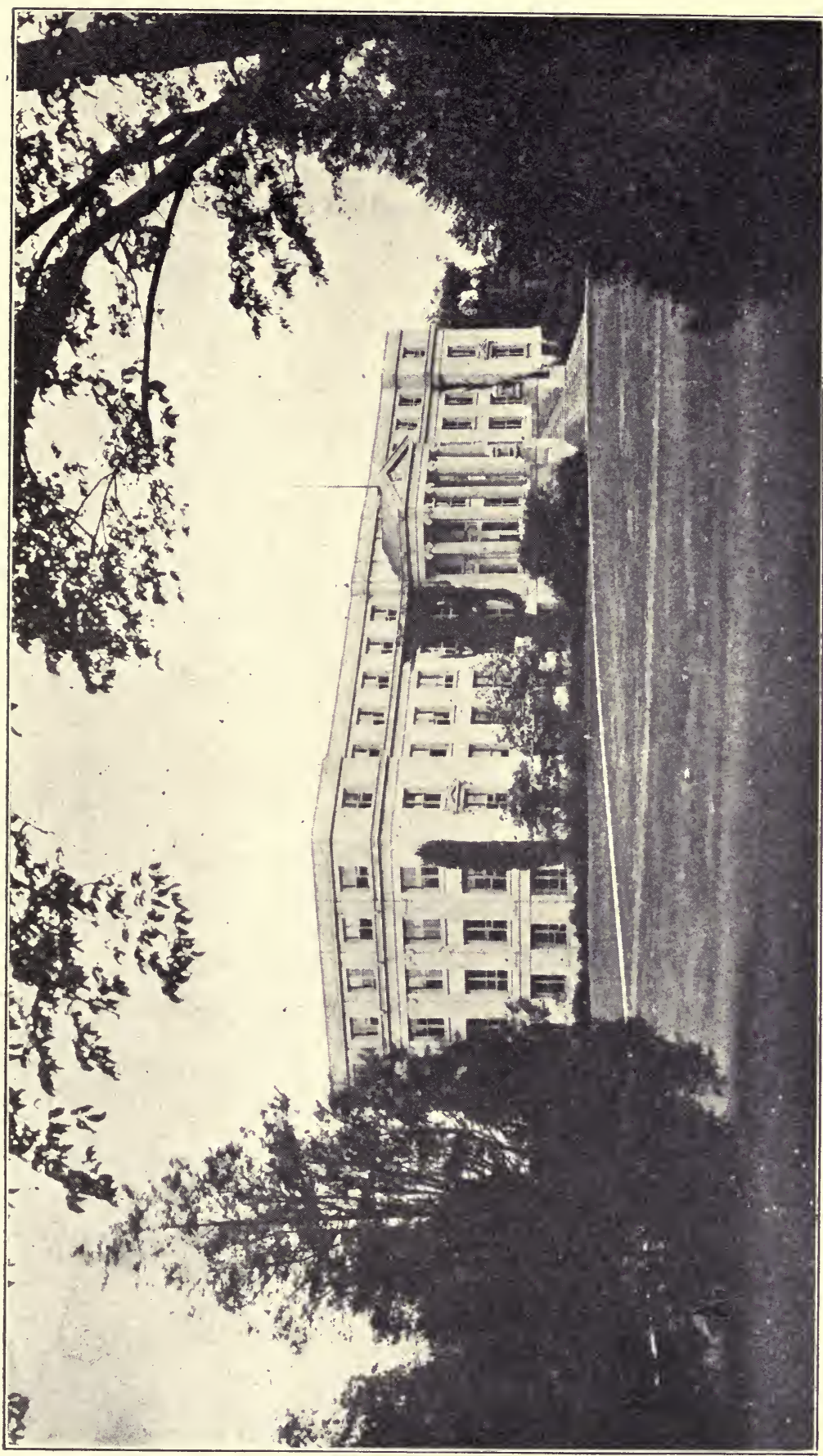


The colleges are under control of boards of trustees, which as a rule are the same as for the experiment stations connected with them. The chief executive officer is a president, under whom is very often a dean in immediate charge of the agricultural work. The number of professors and assistant teachers of agriculture varies greatly, but the larger and more wealthy institutions now have agricultural faculties of 20 or more teachers. These-institutions are in general equipped with a number of substantial buildings and large farms used for agricultural instruction, herds of different kinds of animals, special scientific apparatus, farm machinery, agricultural libraries, etc., in addition to the equipment used for instruction in natural sciences, languages, mathematics, and other subjects usually included in college courses

There are at present 48 State institutions in which college instruction is given to white students and I7 colleges for colored students in the Southern States. Similar institutions are maintained in Porto Rico, Hawaii, and the Philippines.

The data available at this time indicate that about $\$ 10,000,000$ was used for agricultural instruction in the land-grant colleges in $192 \mathrm{r}$.

Under the head of agriculture, instruction is given in plant production (including agronomy [field crops], horticulture, and forestry), animal production, agricultural technology (e. g., dairying, sugar making), rural engineering, rural economics, and sociology. There is also instruction regarding plant and animal disease, injurious insects, and predatory animals. In the agricultural courses special emphasis is laid on those subjects most important to the agriculture of the region in which the college is located. Thus dairy farming is emphasized in the Northeastern States, cotton farming in some Southern States, the growing of wheat, maize, and other cereals in the North-Central States, dry farming and irrigation in the Western States, fruit growing in the Pacific Coast States and Florida.

Combined with the instruction in agriculture, courses are given in natural sciences, mathematics, languages, history, political and social science, etc., in order that the graduate in agriculture may have a liberal as well as a practical education.

The amount of time devoted to agricultural subjects during the regular four-year course varies in different colleges, but averages about 40 per cent. In some colleges emphasis is laid on the fundamental sciences during the first two years, but the present tendency is to give a considerable amount of agricultural work in those years. There is much elective work during the third and fourth years, in which the student is expected to give special attention to some subject of particular interest to him and to combine with this a group of studies to make a well-rounded course. This group system of electives is now much more favored than a system of free electives, which of ten results in too narrow specialization or too superficial work on too many subjects. 
The regular college courses in agriculture are based on four years of study in a secondary (high) school and seven or eight years in an elementary school. The entrance requirements on this basis include instruction in English, mathematics, history, and elementary science, usually combined with Latin, or a modern language, or agriculture. The giving of entrance credit for agriculture is a comparatively new thing and thus far only a few students have satisfied the requirements in this subject.

In recent years the agricultural colleges have undertaken the professional training of teachers of agriculture and for this purpose have established departments of agricultural education. Courses in educational psychology and the principles and methods of teaching, with special reference to the teaching of agriculture, are given, usually in the third and fourth year of the college course. Teachers in service are also given opportunities for professional advancement by means of short courses, particularly in connection with the summer term of school.

Since the passage of the Smith-Hughes Vocational Education Act in I9I 7 the agricultural colleges have been designated to carry out the provisions of that act relating to the training of teachers of agriculture. This has greatly strengthened their departments of agricultural education.

The four-year courses in agriculture ordinarily lead to the degree of bachelor of science (in agriculture). Graduate courses are now given in a number of the colleges leading to the degree of master of science or doctor of philosophy. Persons preparing to become investigators, teachers, or agricultural experts are recommended to take graduate courses.

Many of the colleges offer short courses of a more practical kind for students engaged in farming or elementary teaching. These vary in length from a few weeks to two years and are usually held in the winter or summer.

\section{SECONDARY EDUCATION IN AGRICULTURE.}

Secondary education in agriculture is given in two types of schools: (I) Special agricultural schools and (2) departments of ordinary secondary (high) schools.

The special agricultural schools are organized as branches of the agricultural colleges or as independent schools in counties or larger districts. Most of these institutions are public schools, but there are also a considerable number of private schools in which agriculture is taught. The special schools usually have their own buildings, farms, live stock, farm machinery, and laboratory apparatus. The fact that they have relatively large equipment for agricultural instruction and more thoroughly vocational courses makes these schools particularly attractive to more 


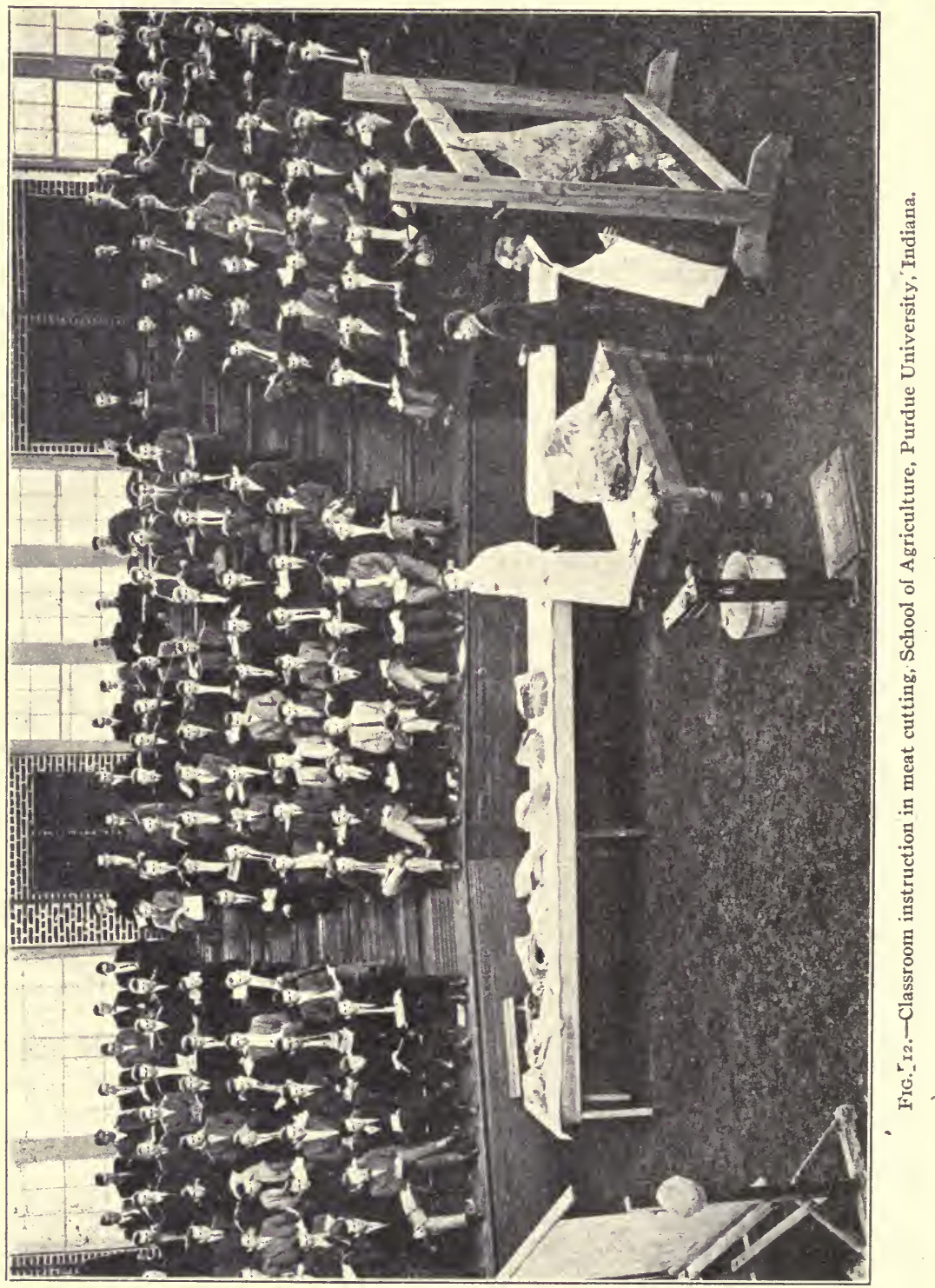




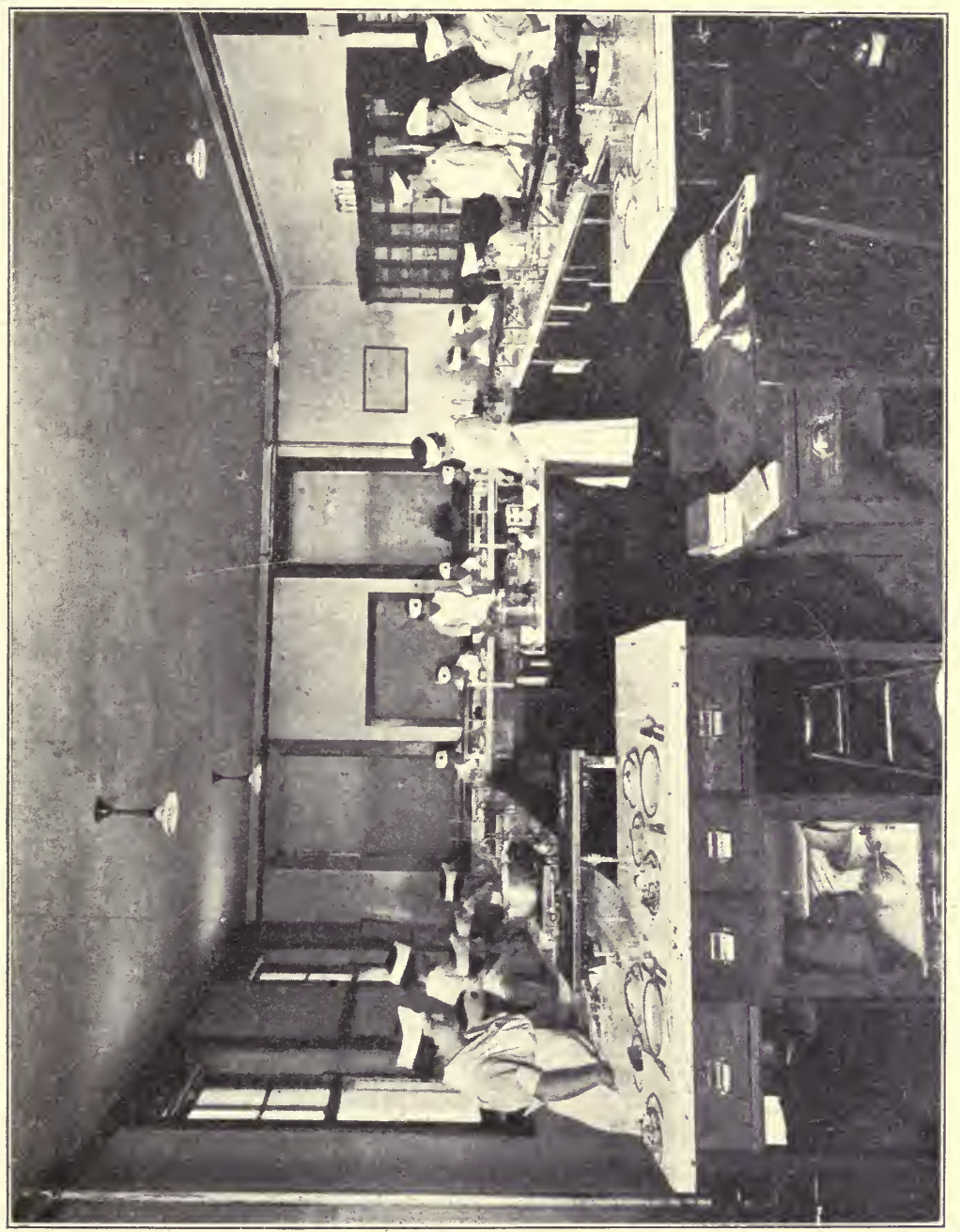

Da 


\section{AGRICULTURE AND HOME ECONOMICS IN UNITED STATES.}

The instruction in agriculture must be of less than college grade and be designed to meet the needs of persons over I4 years of age who have entered or are preparing to enter upon farm work. Each student in agriculture must pursue supervised practice in agriculture on a farm for at least six months per year. Under this act it has been possible to establish more definite standards for secondary instruction in agriculture and to enforce a larger requirement of practical work definitely connected with the instruction in the school. The "home projects" of the students usually consist of the growing of some crop on at least an acre of land or the feeding and care of one or more animals for a period of at least six months. The student must keep a record of his farm operations and their cost and make a written report on his project at its completion. The teacher visits the farm to observe and comment on the work. Care is also taken to connect the school instruction with the practical work on the farm. A considerable number of the special agricultural schools have received these funds and they have also gone to a large number of public high schools. In I92I, 50 special schools and I,700 ordinary high schools received the Smith-Hughes funds.

\section{ELEMENTARY EDUCATION IN AGRICULTURE.}

Twenty-two States have special laws dealing with the teaching of agriculture in the public elementary schools, at least in rural communities. It has, however, been difficult to secure satisfactory teaching of this subject in these schools generally. Most of the teachers in the rural elementary schools are young women without training in agriculture. If they have attempted to teach agriculture they have simply used a textbook in a perfunctory way. A few teachers in the one-room schools have, however, been able to interest the pupils and to give them some worth-while and practical instruction in this subject. More has been accomplished in the larger schools formed by the consolidation of a number of small school districts within a township. In these "consolidated" schools a teacher trained in agriculture is often employed.

As a rule the formal teaching of agriculture has been confined to the seventh and eighth. grades, in which the pupils are usually over I 2 years old. In the lower grades there is often some nature study, which involves observation of common plants, domestic animals, birds, insects, etc., and thus is introductory to instruction in agriculture.

A considerable number of textbooks in elementary agriculture have been published and widely circulated. Many of the States have prepared outline courses in agriculture for the elementary schools. In this work the State departments of education, agricultural colleges, and United States Department of Agriculture have of ten cooperated. Charts, lantern slides, and other illustrative material have also been provided by public and private agencies. The extension agents of the agricultural colleges and United States Department of Agriculture have also 
mature students who have not been able or inclined to prepare for college, but desire instruction which will make them better farmers. Since most of their students reside at considerable distance from the schools, the expense of attendance is materially increased as compared with that of the student who attends a near-by high school. Such schools, therefore, will not be numerous and will not take the place of the best high schools easily accessible to farm children who have completed courses in the elementary schools and who because of their age and other conditions should reside at home.

The courses of instruction in agriculture in the special schools vary considerably in duration and subject matter according to the agricultural conditions in different regions and the size of the faculty and equipment of the school. In general, courses in agriculture covering from two to four years are combined with courses in English, mathematics, elementary science, history, civics, and manual training to make a fouryear secondary course. Systematic practice in farm operations is included in the agricultural course.

A department of agricultural instruction has been organized in about 2,000 public high schools in the 48 States and in a small number of private schools. In each school there is usually a single teacher of agriculture. In most of these schools the agricultural course covers only one or two years, but in an increasing number of schools an effort is being made to continue it through the four years covered by the regular high-school program. The instruction varies from that which is largely practical and truly vocational to that which consists chiefly of textbook and laboratory work. Some of the schools have small tracts of land and a few animals, but for the most part the practical work is conducted on the farms where the students reside with their parents through what are known as home projects.

Since 1917 secondary agricultural instruction has been increasingly influenced by the provisions of the Smith-Hughes Vocational Educational Act. Under this act in $1917, \$ 548$, o0o of Federal funds was allotted to the States on the basis of their rural population for the salaries of teachers and; supervisors of agricultural instruction. This amount has been annually increased by $\$ 250,000$ and this will continue until 1926, after which the annual appropriation will be $\$ 3,000,000$. To obtain these Federal funds the States must accept the provisions of the act, after which they receive as much of their share of this fund as they offset with State funds. All the States have accepted this act and many of them have thus far contributed more than enough to entitle them to their full quotas of Federal funds.

The supervision of these funds is intrusted to State boards of vocational education, by whom they are allotted to such schools teaching agriculture as are approved by the State board and meet the general requirements of the act as administered by the Federal Board for Vocational Education. 


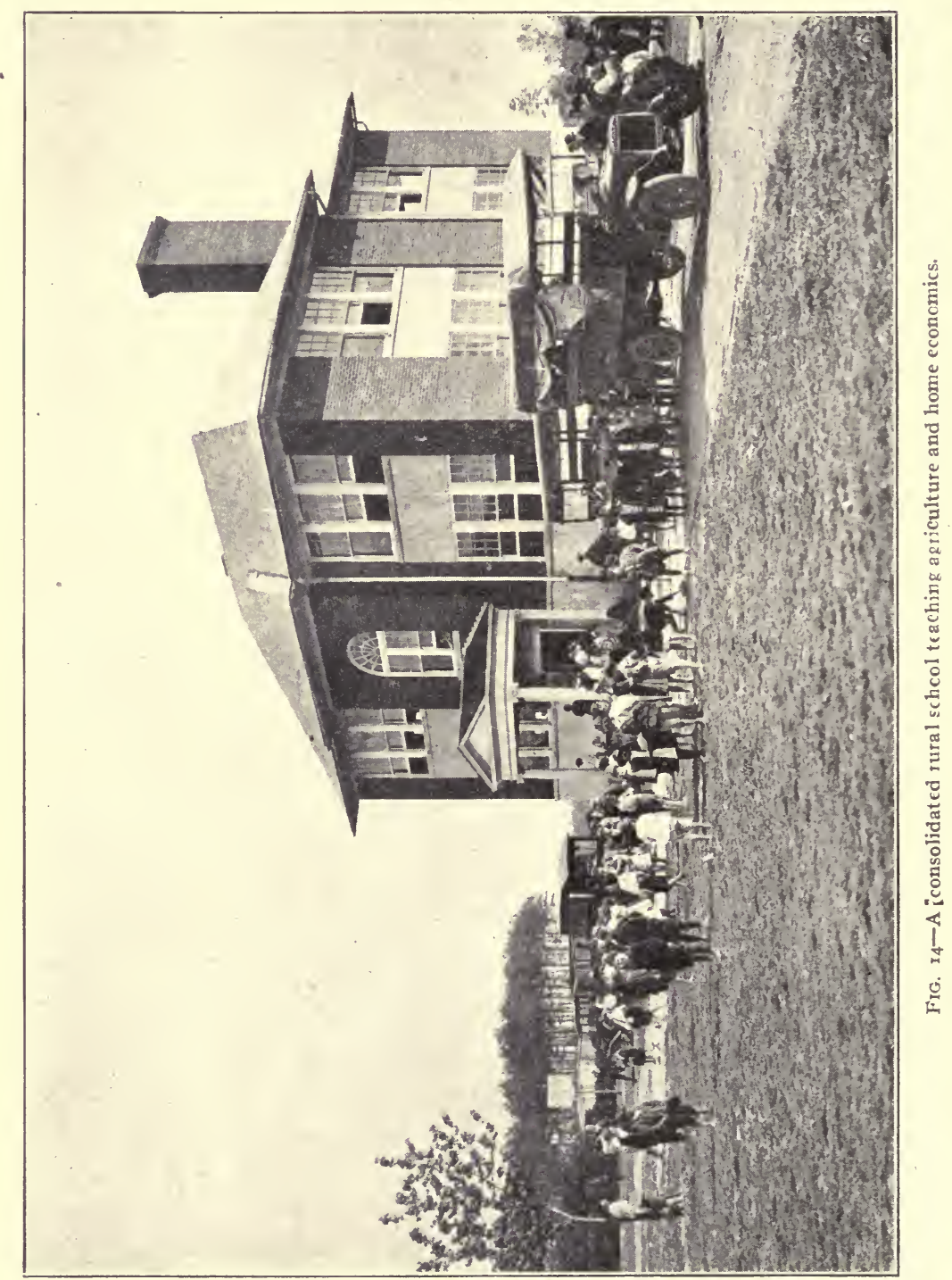


aided the teachers to make the instruction more practical. In many schools the children have been enrolled in the clubs organized by the extension agents and thus have grown crops or animals under expert supervision, this work serving as a "home project" and being linked with the school instruction.

Many State normal schools have included agriculture in their teachertraining courses and the agricultural colleges have also aided in this work. A few normal schools have undertaken experiments with new forms of curricula and methods of instruction in an effort to suggest ways by which elementary rural schools may be made better agencies for fitting children to live in the open country and engage successfully in farming.

EXTENSION WORK IN AGRICULTURE AND HOME ECONOMICS.

From their beginning the agricultural colleges and the United States Department of Agriculture have sent out members of their staffs to make addresses at farmers' meetings. They have also distributed publications. The popular publications of the department, particularly the Yearbook and the farmers' bulletins, and the bulletins of the experiment stations have been freely distributed in very large numbers. An enormous correspondence on agricultural subjects has also been conducted by the agricultural institutions.

About 50 years ago the agricultural colleges and State boards or departments of agriculture began to hold annual series of meetings in different parts of the State, at which addresses were delivered by experts and successful farmers, followed by questions and discussion from the audience. These meetings, lasting from one to three days, have been called farmers' institutes. They proved so popular that State legislatures made special appropriations for their maintenance. Regular staffs of lecturers were employed and special publications were issued. The number of meetings grew up to several thousand annually. The total attendance mounted until it aggregated several million. Special institutes for women and young people were added. Music and other recreational features were introduced and in recent years lantern slides and moving pictures have been increasingly used.

About 20 years ago, when farmers in the Southern States became alarmed at the spread of the cotton-boll weevil, the Department of Agriculture, under the leadership of Dr. Seaman A. Knapp, undertook to establish demonstrations of improved methods of agriculture on farms in that region. The farmers carried on these demonstrations under the supervision of department agents. Meetings were held at the demonstration fields. This plan proved so successful that after a time special agents were located in single counties to supervise the demonstrations and further assist the farmers. To benefit farm boys and girls clubs 
were formed, whose members undertook some special work at home, such as raising an acre of corn or a pig or canning vegetables or fruit. Then it appeared that the farm women should have special assistance in their gardening and poultry raising and in conserving and stilizing their products and improving their home conditions. Women agents were therefore placed in counties where funds were available for their support.

This system of extension work spread rapidly in the Southern States until several hundred county men and women agents were regularly employed, with Federal, State, and district agents to supervise them. At first this movement was independent of the agricultural colleges, but gradually they were drawn into cooperation with it. Later a similar system spread into the Northern and Western States, where the colleges took an active part in it.

Maintained at first wholly with Federal funds, it afterwards received for several years much of its financial support from large private concerns, as well as from States and counties.

The general extension movement among the farmers culminated in I9I4 through the passage by Congress of the Smith-Lever Extension Act, which made possible a combination of the demonstration work with useful features of the earlier extension work, so as to form a broad system of practical education for the men, women, and children on the farm, supplementary to the training given in schools and colleges. Under this act the agricultural colleges and the Department of Agriculture are made responsible for cooperatively carrying on the extension system, which thus becomes a permanent part of the public system of education throughout the 48 States.

The act provides that the States accepting its provisions shall designate colleges receiving the benefits of the land-grant act of 1862 and the Morrill Act of 1890 to receive and use the Federal and State extension funds. The work must be done in cooperation with the Department of Agriculture and in accordance with plans mutually agreed upon by the Secretary of Agriculture and the several agricultural colleges.

Ten thousand dollars of Federal funds are annually appropriated to each State, together with additional funds allotted to the States on the basis of rural population. The additional funds to be thus allotted began with $\$ 600,000$ in 1915 and thereafter are increased by $\$ 500$, o0o for seven years, at the end of which they will be $\$ 4,100,000$ annually. These additional funds must be offset by equal amounts which may be appropriated by the State legislature "or provided by State, county, college, local authority, or individual contributions within the State."

In the year beginning July I, I92 I, the extension work in the States is maintained with $\$ 18,500,000$, divided as follows: 


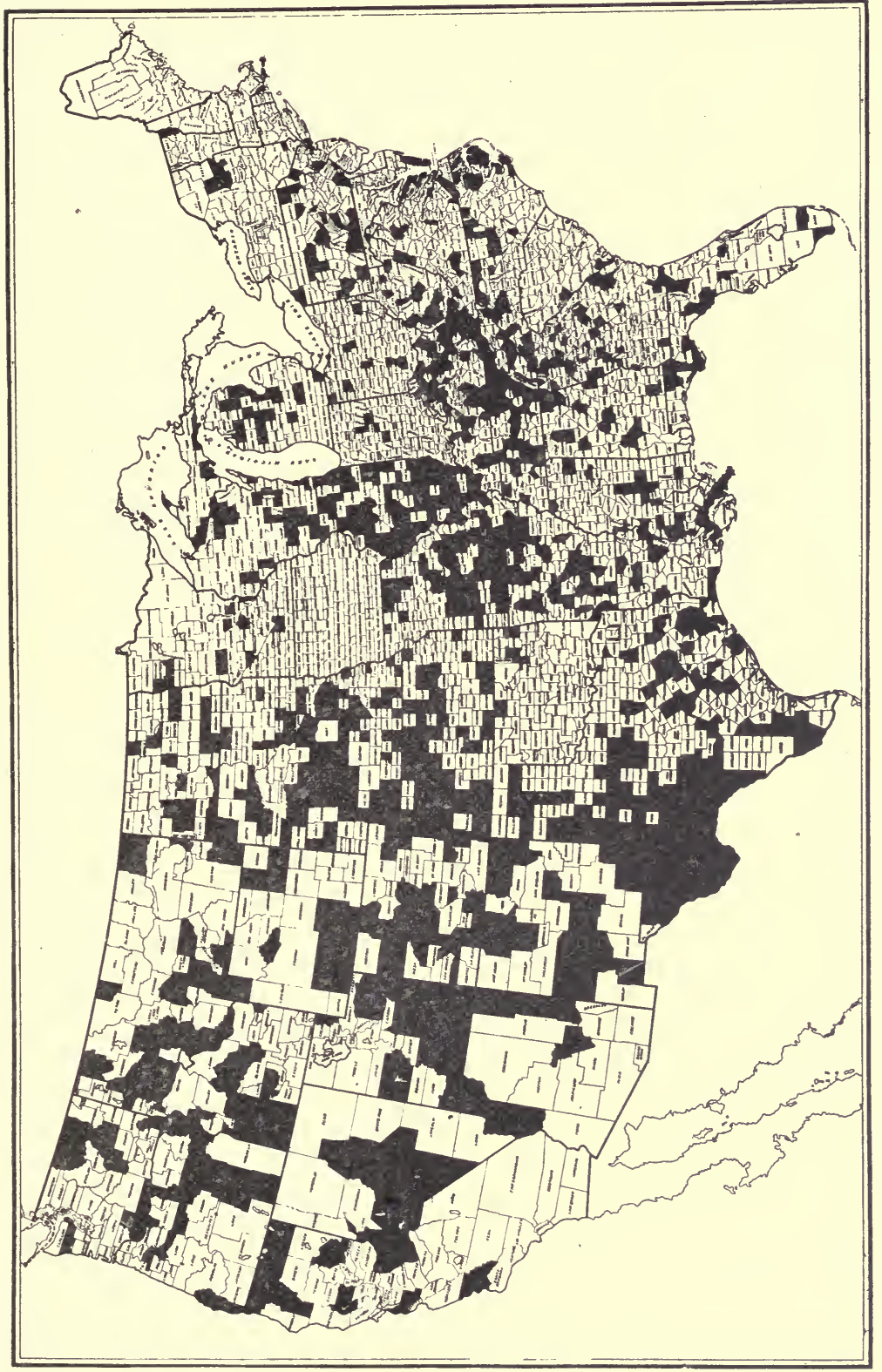

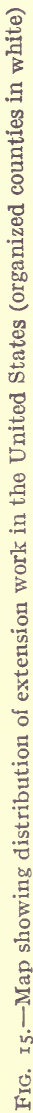




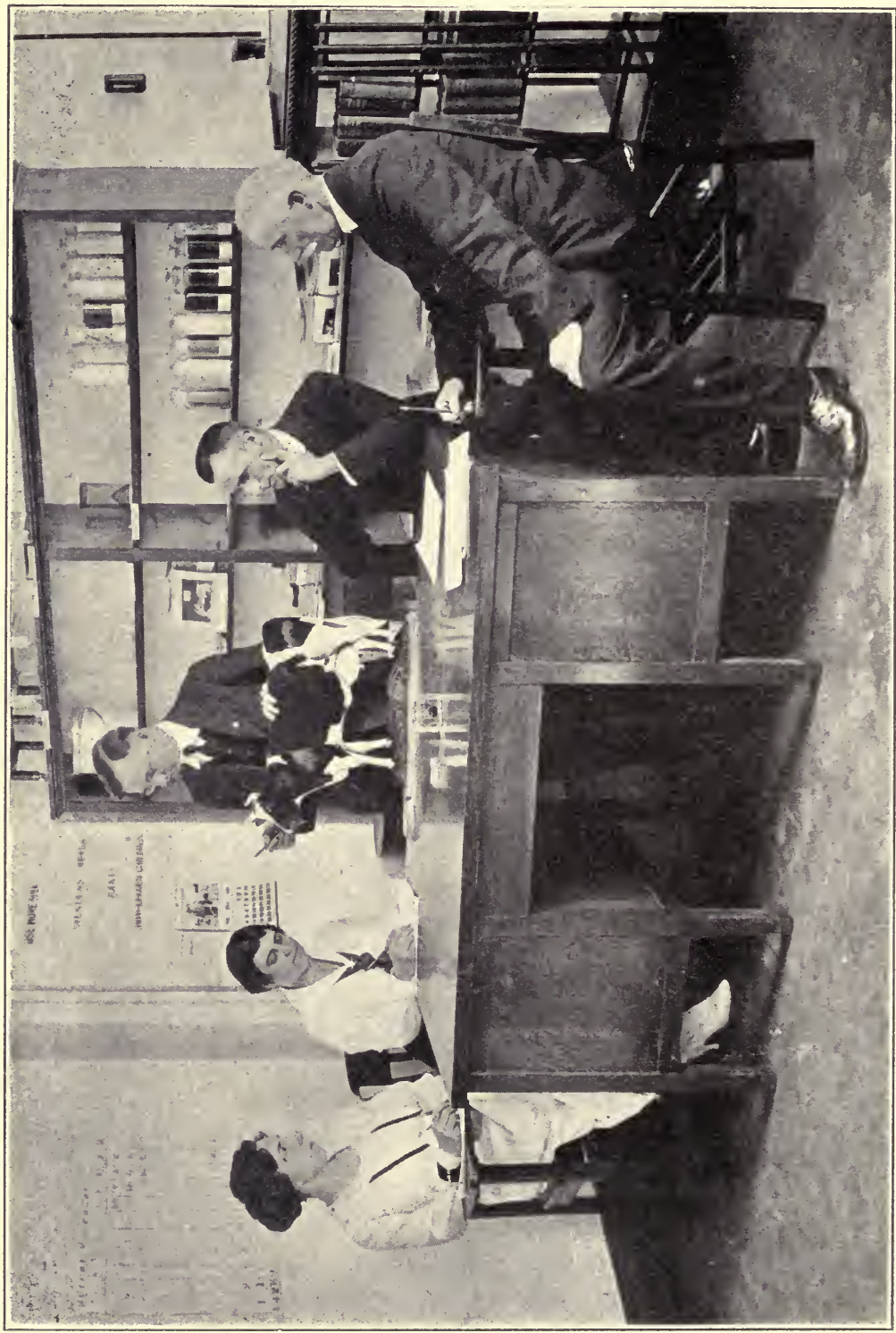


Federal Government:

States Relations Service................. \$1, 050, 754

Other bureaus of Department of Agriculture......... 100, 205

Federal Smith-Lever funds:

Regular........................... 4, 080,000

Supplementary...................... I, 500,000

From sources within the State:

$\$ 6,730,959$

To offset Federal Smith-Lever funds-

Regular............................ 3,600,, 00

Supplementary....................... I, 500,000

Additional funds from States, counties, and other sources... • 6, 666, 40 I

II, 766,401

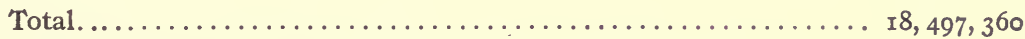

Since the passage of the Smith-Lever Act Congress has made annual appropriations supplementary to the regular Smith-Lever funds and also providing the States Relations Service of the Department of Agriculture with funds to be used in cooperation with the colleges and counties in extension work. The States and counties have more than met their obligations under the Federal legislation.

In the relations of the Federal Government with the cooperative extension service the Secretary of Agriculture is represented by the Assistant Secretary as far as general policies and administration are concerned. The director of the States Relations Service is responsible for the general management of the department's affairs relating to extension work. This business is principally conducted through an Office of Extension Work in the States Relations Service. The chief of that office and his assistants confer with the State extension officers and make agreements with them regarding projects and plans of work, financial budgets, and methods of conducting the work in the States and counties. They also make arrangements for the cooperation of specialists from the department bureaus in the work in the States. The work and expenditures under the Smith-Lever and department funds are annually inspected in all the States, and when the expenditures are approved the States are certified to the Treasury Department to receive the next installment of the Smith-Lever fund. The funds appropriated to States Relations Service for farmers' cooperative demonstration work are used for the maintenance of the Office of Extension Work and for the payment of part of the salary of extension workers in the States and counties.

In the States each college receiving the Smith-Lever fund carries on its extension work through an extension division, at the head of which is a director, who acts as the joint representative of the Department of Agriculture and the college and administers all the extension work in the State. Under him are State leaders of the county work and a force of extension specialists in the various branches of agriculture and home 
economics who assist the county workers and supplement their work throughout the State. They also prepare publications and illustrative material.

In 2,100 counties out of about 2,650 agricultural counties there is an agricultural agent, in 800 counties a home demonstration agent, and in 200 counties a special agent for boys' and girls' club work. These agents supervise and conduct demonstrations on the farms and in the homes, hold meetings, and give advice and assistance by personal visits, correspondence, telephone messages, articles in the local press, etc.

To support and aid the county workers, groups of farm men and women have been organized. In about 1,500 counties this organization is called a farm bureau. It has a president, secretary, nd treasurer, and committees whose members represent different communities in the county. About a million persons are members of farm bureaus. While originally formed to cooperate in extension work, the farm bureaus have enlarged the scope of their work to include the formation of marketing organizations, publishing of papers, and matters relating to business, legislation, and the social concerns of farming communities. The extension workers are not responsible for the conduct of these activities, though they may give advice and information regarding them. The farm bureaus often use part funds as contributions to the support of the county extension workers. For their larger enterprises State and American federations of farm bureaus have been formed.

In about 600 counties the place of the farm bureau is filled by a county council of agriculture or some other organization of farmers. Throughout the country the extension workers also have helpful relations with many kinds of farm organizations.

In making the annual plans for extension work it is now a common practice for community committees of farming people to meet together with the extension agents and work out a community program. These community programs may then be combined into a county program. Certain features of the county programs may then be taken to form a State program, and this may have certain elements of regional or national significance.

The character of the cooperative extension work is defined in the SmithLever Act as follows:

That cooperative agricultural extension work shall consist of the giving of instruction and practical demonstrations in agriculture and home economics to persons not attending or resident in said colleges in the several communities, and imparting to such persons information on said subjects through field demonstrations, publications, and otherwise.

In subject matter this work covers the whole range of problems relating to agricultural production and economics, as well as the home and community life of farming people. In recent years the agricultural agents have given much attention to standardization and marketing 


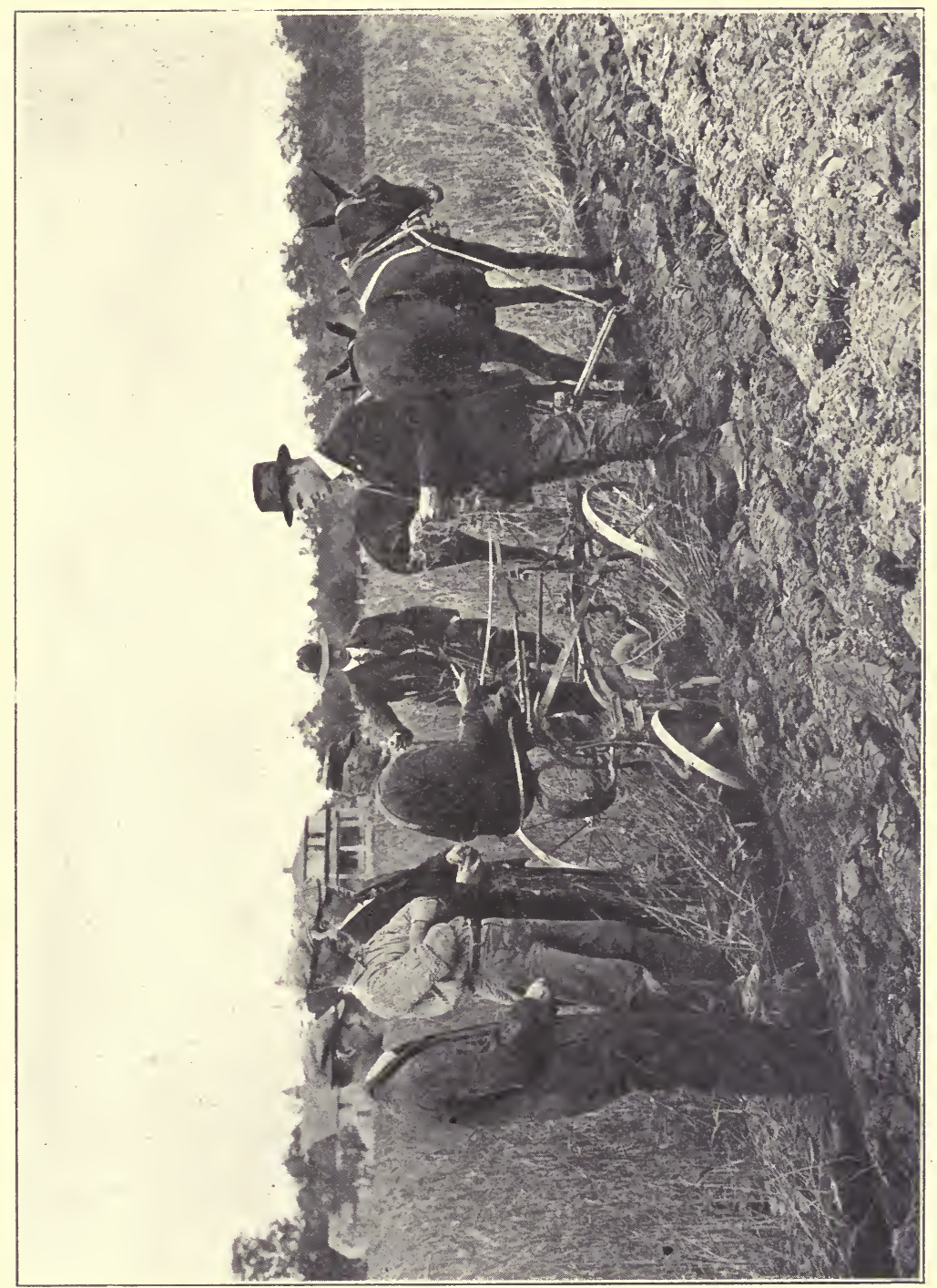


34 AGRICULTURE AND HOME ECONOMICS IN UNITED STATES.

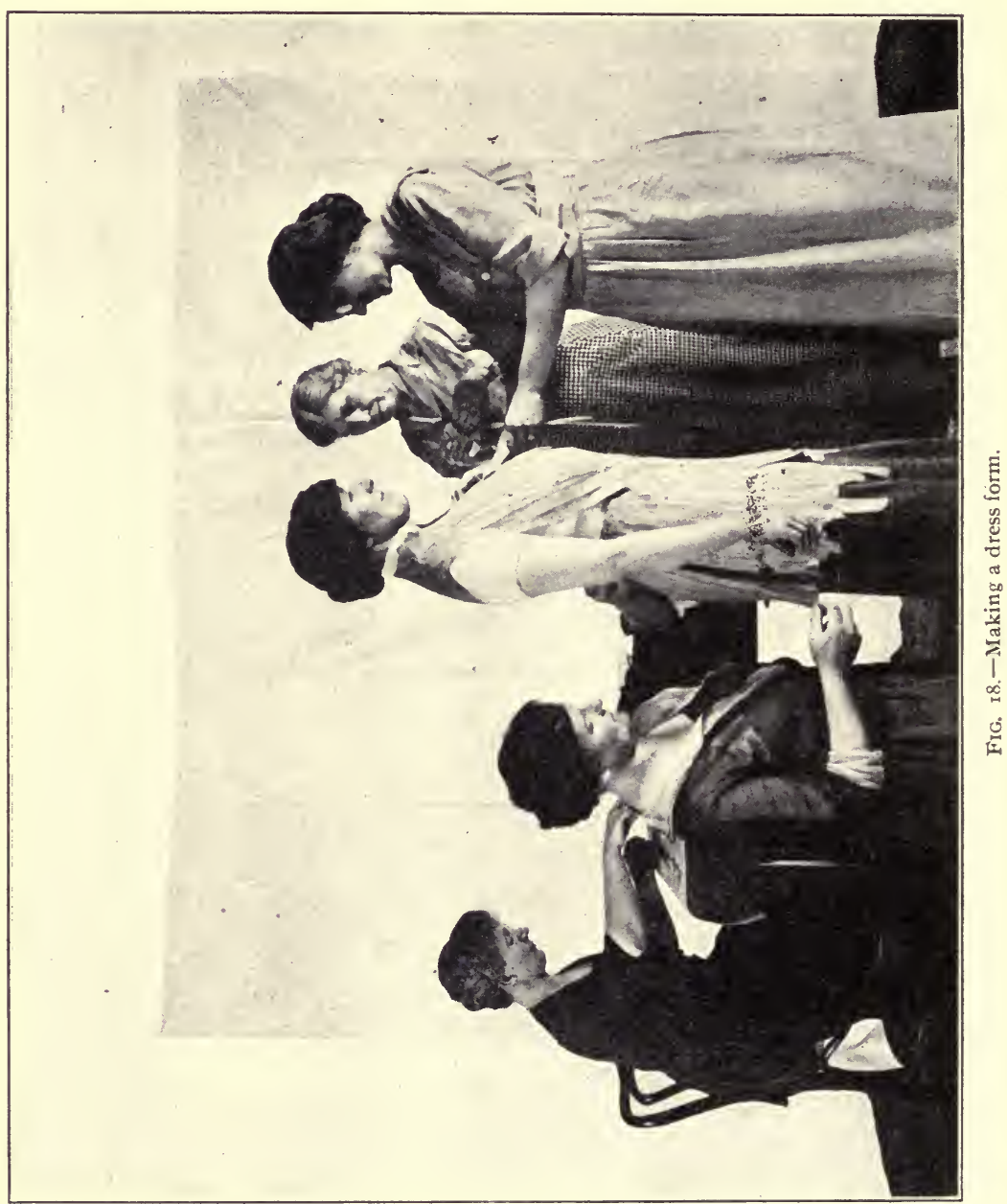




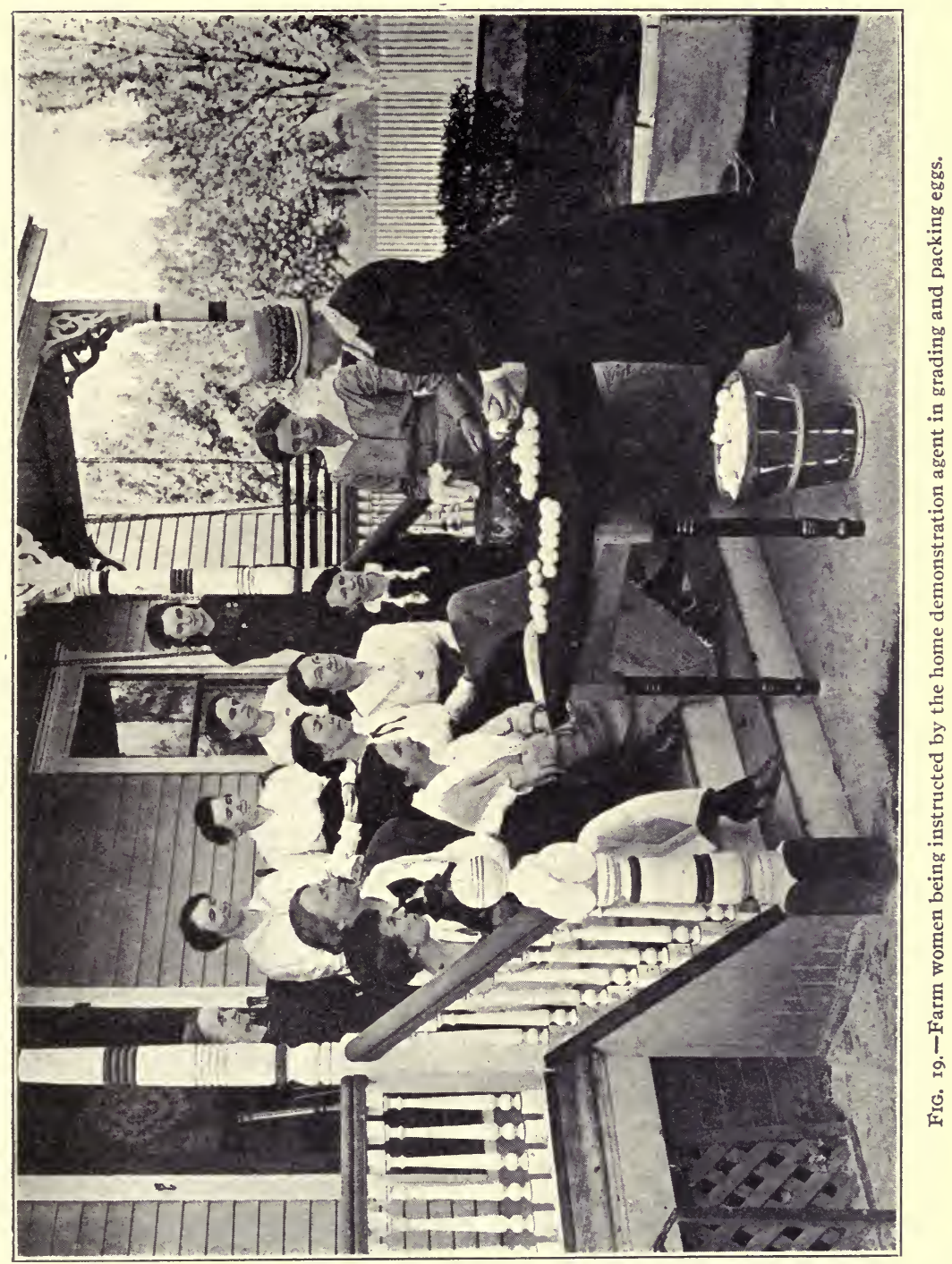




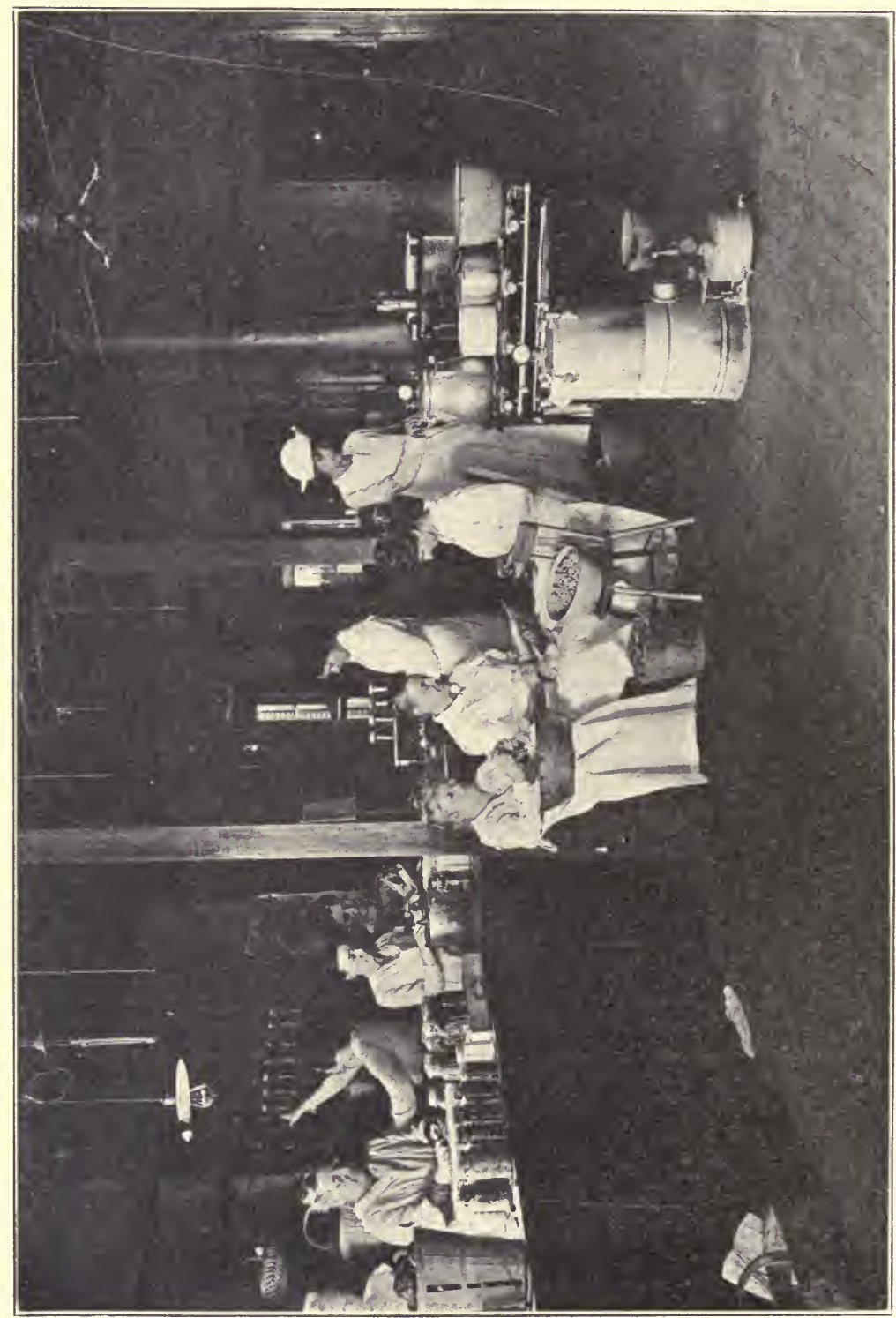




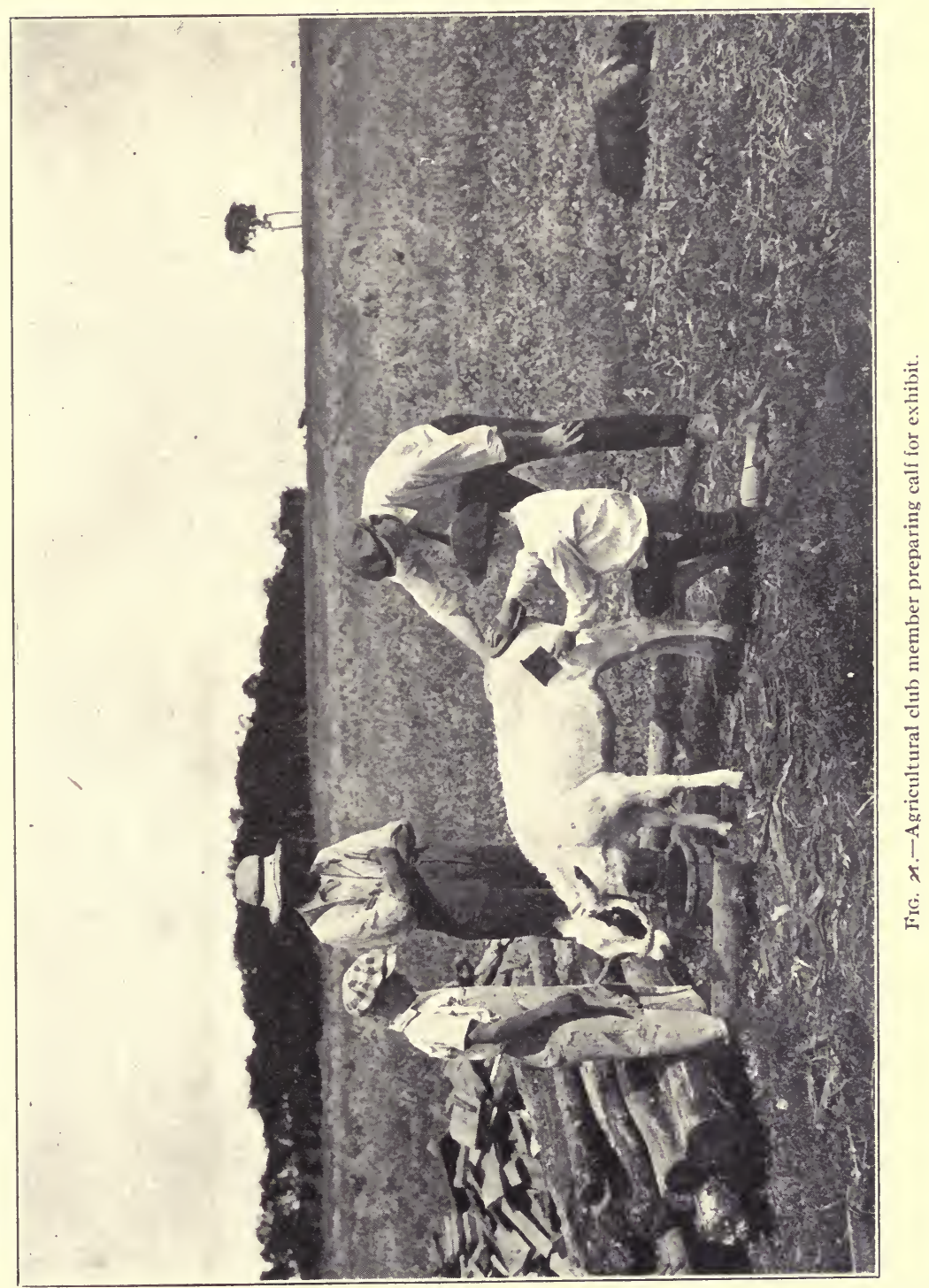


38 AGRICULTURE AND HOME ECONOMICS IN UNITED STATES.

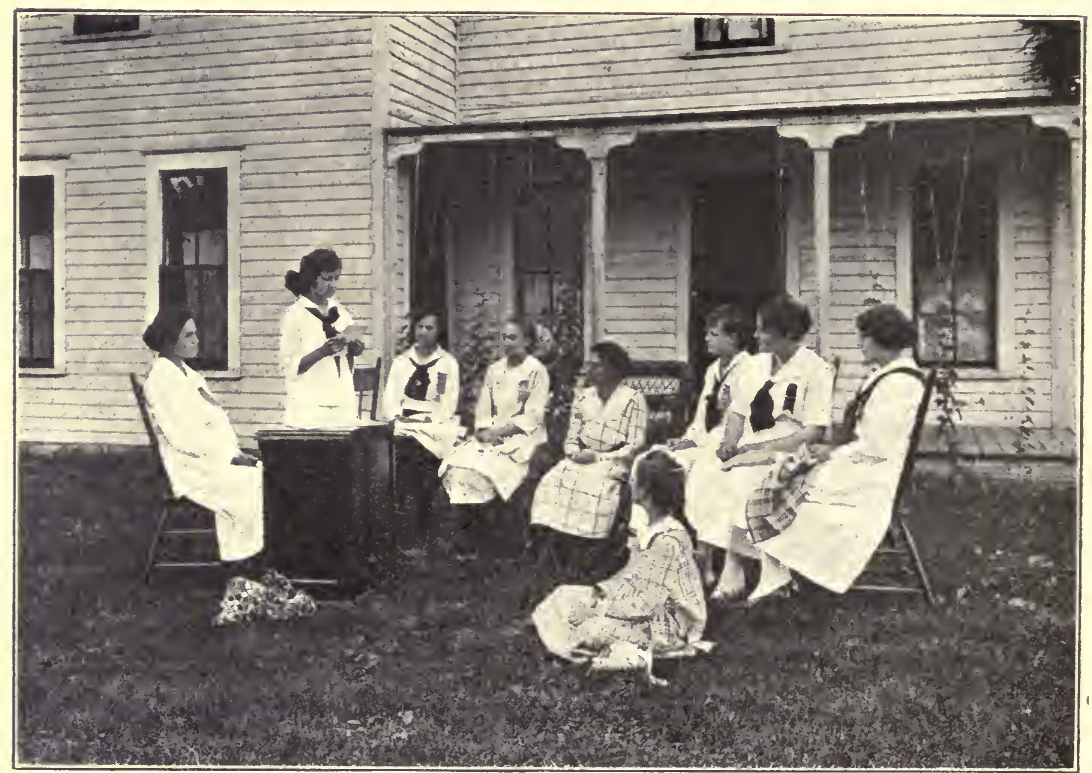

I'1G. 22.-Girls' club meeting. 
of farm products and the formation of cooperative associations. The home demonstration agents have aided the farm women in increasing and more efficiently utilizing their farm products and incomes, bettering sanitary conditions, preventing diseases, improving household arrangements and equipment, using labor-saving devices, and increasing social welfare.

The following summary illustrates some features of the extension work in $192 \mathrm{I}$ :

In the organized counties work is carried on in cooperation with clubs, committees, and other groups of farming people in 25,000 communities.

During the year 125,000 community and other meetings were held with an attendance of $6,000,000$.

The county agricultural agents, assisted by the State leaders and extension specialists, visited 650,000 farms, on about 250,000 of which they carried on demonstrations with a large variety of crops and animals. In connection with these demonstrations, 75,000 field meetings were held with an attendance of $1,000,000$.

The number of farmers who modified their crop or live-stock production as the results of extension work was 2,215,000, or an average of about I, roo per county.

As an example of what is accomplished through demonstration work, the agents reported that $\mathrm{r}, 600,000$ acres were planted with selected seed corn and that 63,000 farmers tested 240,000 bushels of seed, which were used in planting $1,600,000$ acres. Due to the influence of the agents, I60,000 farmers selected nearly a million bushels of seed corn for use next year. The agents were also influential in getting $4 \mathrm{I}, 000$ farmers to treat $2,600,000$ bushels of seed wheat for smut, which were used for planting $2,800,000$ acres, and, similarly, 83,000 farmers to treat $\mathrm{I}, 250,000$ bushels of seed oats used in planting 750,000 acres. The agents also conducted nearly 30,000 demonstrations in the introduction or improvement of the practice in connection with legumes, over 350,000 farmers adopting the practices demonstrated.

The State and county home demonstration agents carried on 250,000 demonstrations, and as the result of these demonstrations 650,000 women made changes in their home practices. Home demonstration work included many matters relating to food, diet, clothing, household equipment, and management. Special emphasis was laid on matters relating to the health of the farming people and the care and nourishment of children in the farm home.

Five hundred thousand boys and girls were enrolled in the clubs and undertook projects on crop and live-stock production. Nearly 300,000 of these completed their projects and made written reports.

The work with swine illustrated how the club work influences the present and future practice of swine production. The 50,000 boys enrolled 
in the pig club work introduced thousands of pure-bred animals into their communities and demonstrated improved methods of feeding. About 186,000 new farmers grow swine for the first time each year. It appears, therefore, that at least one-fourth of the future swine growers received some training through the club work. Twenty-four thousand, or nearly 15 per cent, of the future swine growers completed the requirements of the club leaders.

The girls and women did a large amount of work in poultry raising, gardening, and food conservation. About 260,000 gardens were established or improved. The canning work included 9,500,000 containers of fruits and vegetables and 7 5,000 pounds of poultry and meat. In addition, 2,600,000 pounds of lard, 3,900,000 pounds of sausage, and $9,450,000$ pounds of cured meat were conserved.

The larger part of the extension work in recent years has related to standardizing and marketing farm products and the formation of cooperative associations. In $192 \mathrm{I}$ the associations which extension agents helped to organize did business amounting to $\$ 77,000,000$, with a saving to farmers of $\$ 9,325,000$. The total business of similar organizations thus far organized amounted last year to $\$ 310,000,000$, with a saving of $\$ 30,000,000$.

White agents did much work which benefited negro farmers and there were also about 240 negro agents, men and women. Over 14,000 negro farmers conducted demonstrations and thus increased their yields of crops on an average of 50 per cent. Fifteen thousand negro boys en rolled in crop and live-stock clubs raised products valued at \$230,000. The negro women and girls canned 225,000 containers of fruits and vegetables and cured or canned over 500,000 pounds of meat. Much work was done in improving negro homes and making their surroundings sanitary. There is very encouraging cooperation of the races in this work.

\section{ELEMENTARY EDUCATION IN HOME ECONOMICS.}

Elementary instruction in subjects within the field of home economics is given in a large number of public and private schools throughout the United States. The work is best organized in the cities, but in the "consolidated" rural schools and in a considerable number of the smaller rural schools useful instruction is given. Cities, counties, and State departments of education often employ special supervising officers to direct and promote home economics instruction in the elementary and higher schools.

In $192 \mathrm{I}$ the Bureau of Education reported that in two-thirds of all the larger school systems "home economics is required of all girls in the seventh and eighth grades," and in a considerable number of cities it is also required in the fifth and sixth grades. In the smaller cities and in the rural communities this instruction usually covers one or two years at the end of the elementary courses. 


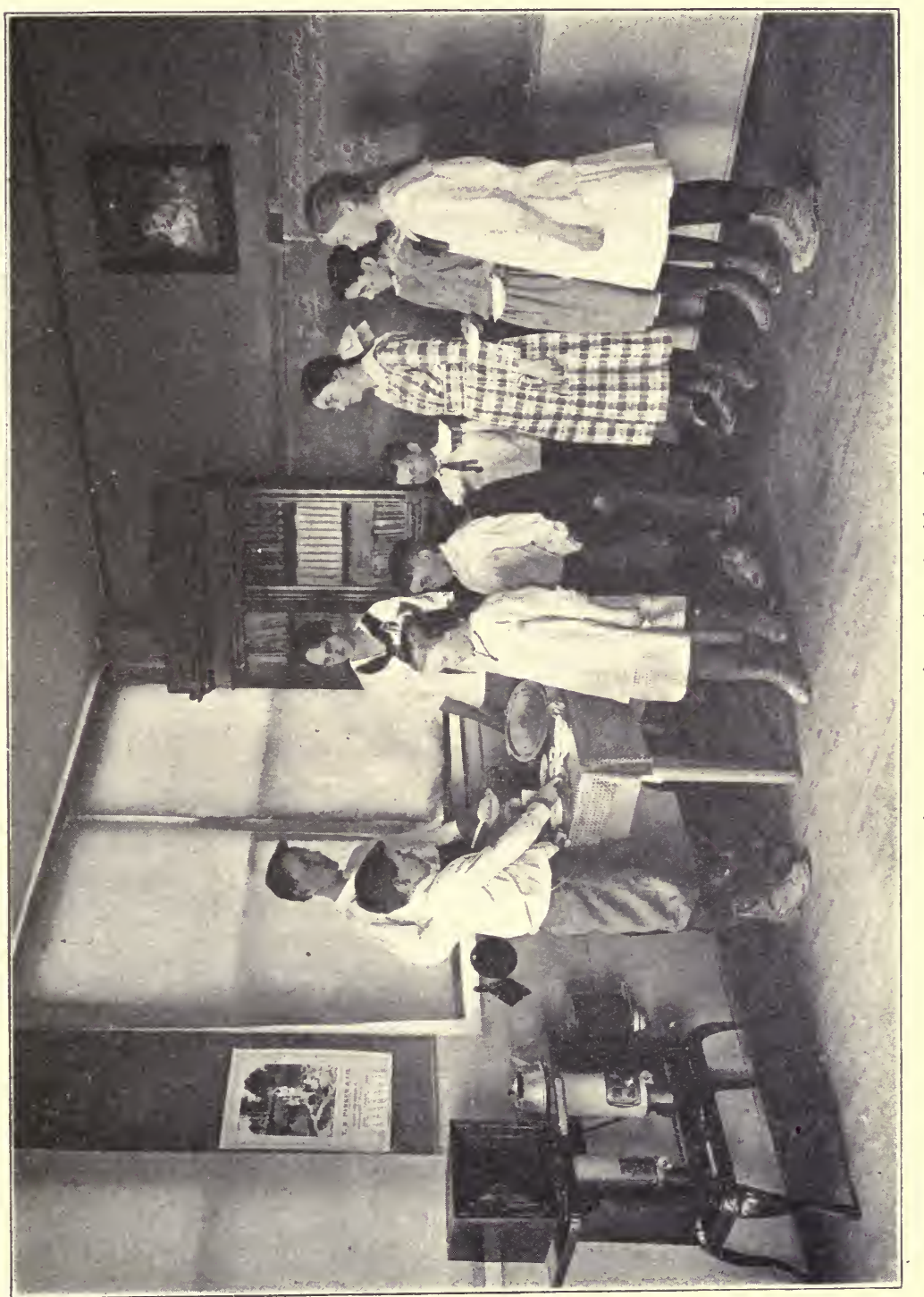


Cooking and sewing, with practice work, form the usual basis of the course. To this is added more or less instruction regarding food, diet, clothing, house furnishing, marketing, home sanitation, home management, and a variety of household arts. ${ }^{1}$ "Establishment of health habits and preparation for home helpfulness are the dominant motives now determining the courses of study and the methods of instruction." Much attention has recently been given to matters of personal hygiene, feeding of children, school lunches, and recording of weight and growth as related to diet.

In many rural schools there is cooperation with the extension agents in the canning of fruits and vegetables and in other work of the girls' clubs. This often results in increased interest among the children and their parents in the instruction in home economics given in the local school.

\section{SECONDARY EDUCATION IN HOME ECONOMICS.}

Courses in home economics are now given in more than 8,000 public high schools and normal schools and in a considerable number of private secondary schools. The time covered by these courses ranges from one to four years.

The four-year course may include instruction in cookery, dietetics, house planning and furnishing, home management, household budgets and accounts. In some of the larger schools vocational courses. in millinery, dressmaking, and other subjects are given. Practice work is done in the school, and in many cases there are also home projects for which school credits are given.

Combined with home economics there will usually be instruction in chemistry, physics, or general science, with applications to household matters, physiology and hygiene, nursing, English language and literature, history, and mathematics. There may also be electives in ancient or modern languages, elementary social and economic science, and other subjects.

Interest in courses which have direct relation to the vocation of home making and to such occupations as dressmaking, millinery, management of restaurants and boarding houses, nursing, etc., has been greatly stimulated by the work being done under the Smith-Hughes Vocational Education Act, since part of the money made available to the States under that act may be spent for instruction in home economics.

For women and girls who are at work and can not take the regular school courses, provision is being made to an increasing extent through part-time and evening courses in food, clothing, millinery, dressmaking, home making, nursing, child care, etc.

In 1921 there were 73 institutions preparing teachers of home economics, of which 13 were preparing teachers for negro schools. Every

1 Much time is also devoted to economics, such as budget making, personal accounts, and to personal and home financial matters. 
State is now offering a course for the preparing of vocational teachers of home economics in day schools, and in addition some of the States have local centers for the training of teachers of part-time and evening schools. In 30 States there are one or more State supervisors of vocational education in home economics under the Smith-Hughes Act.

\section{HIGHER EDUCATION IN HOME ECONOMICS.}

Over 300 colleges and universities maintain courses in home economics, employing for this purpose over 1,000 teachers. These institutions include most of the State universities and land-grant colleges, State colleges for women, and private colleges and universities. Home-economics departments of college grade are also maintained by a considerable number of normal schools and by junior colleges and other institutions offering two years of college work.

The home-economics courses vary from those of limited scope, given as a part of a broad education for women, to elaborate and highly specialized courses leading directly to various vocations, including teaching or research. In a general way the first two years of the regular college course include instruction on food and diet, clothing and household equipment and management, combined with sciences such as physics, chemistry, bacteriology and physiology, English language and literature, and at least one foreign language as required subjects. There may also be a small number of electives in these years. In the third and fourth years the student is expected to pursue certain major subjects and electives, varying in amount and number with the size of the faculty and the general character of the instruction.

Among the special courses offered in different institutions are those on nutrition, dietitian service, child feeding, care and welfare; nursing; household entomology; house furnishing and decoration; household art; textiles; business of housekeeping; household administration; institutional management; and teacher-training.

The four-year courses in home economics lead to the bachelor's degree. A number of institutions also give courses leading to advanced degrees.

The home-economics departments are equipped with laboratories, kitchens, dining rooms, laundries, bedrooms, parlors, classrooms, and special apparatus. A number of institutions also have practice houses, in which the students carry on all the operations of a household, and at the same time do the marketing, keep accounts, and perform other business connected with household management.

RESEARCH IN HOME ECONOMICS.

Experiments and other research in the field of home economics have been conducted by a number of universities and colleges in different parts of the United States. The largest organization for this purpose 
44 AGRICULTURE AND HOME ECONOMICS IN UNITED STATES.

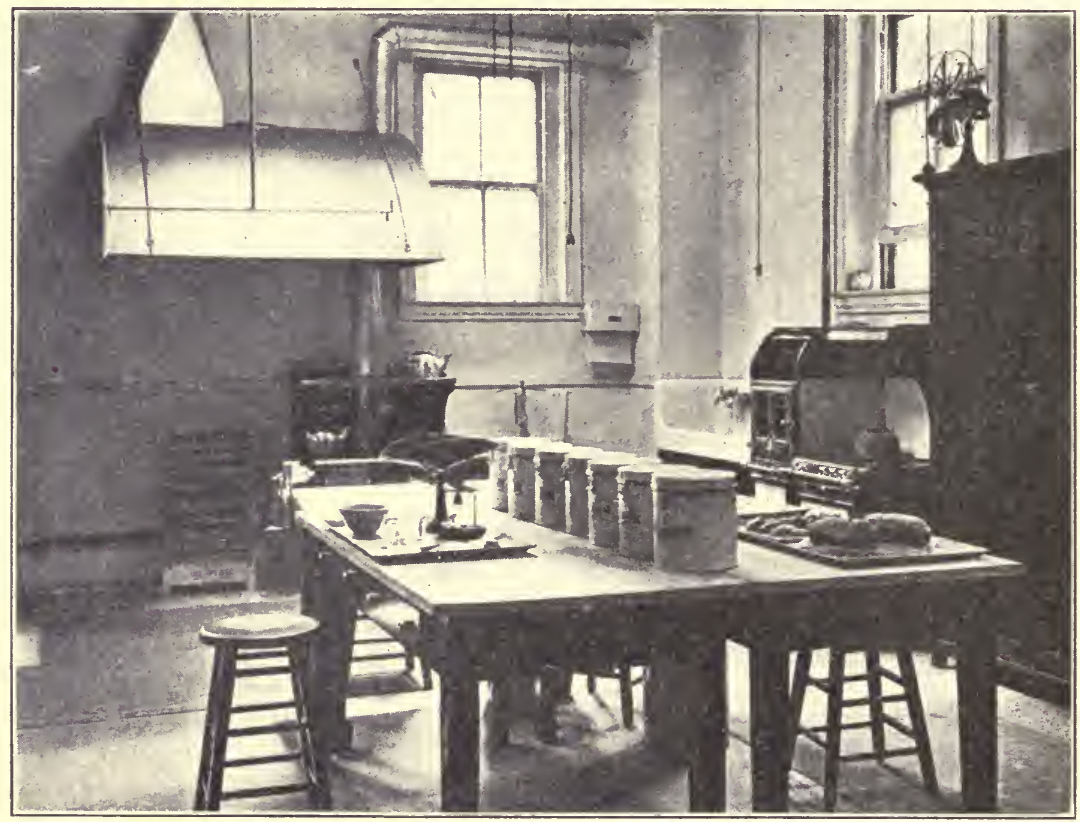

Fig. 24-Interior view of the Experimental Kitchen, Office of Home Economics, United States Department of Agriculture. 
is the Office of Home Economics in the United States Department of Agriculture.

This office was established in the States Relations Service in I9I 5 and was a continuation and enlargement of the nutrition investigations of the Office of Experiment Stations. About r89o Dr. W. O. Atwater, professor of chemistry at Wesleyan University and director of the Storrs Experiment Station in Connecticut, began investigations in human nutrition. Beginning with 1894 this work was granted Federal funds and later on was transferred to Washington as a branch of the Department of Agriculture.

The earlier work consisted of dietary studies and digestion and metabolism experiments. Professors Atwater and Rosa devised an elaborate apparatus called a respiration calorimeter, in which human subjects could live for a number of days, while the energy value of their diet was being determined in relation to the energy expended in various kinds of work performed in the calorimeter. Improved apparatus of this kind is now used in the laboratory at Washington, where its scope has been extended to include the study (in cooperation with other bureaus) of fundamental problems of agriculture as well as those pertaining more directly to the home and its management. Dietary studies of persons engaged in various occupations have been carried on in different parts of the country, partly in cooperation with universities and colleges. Numerous digestion and metabolism experiments with great varieties of food have been made. The results of nutrition investigations in many countries have been compiled.

In recent years the work of the Office of Home Economics has been enlarged to cover studies of the preparation of foods and meals, of clothing, textiles, different kinds of household equipment, household accounting and management, etc. A special laboratory has been equipped for the study of the preparation of food, particularly with a view to obtaining more exact knowledge regarding matters involved in cooking, in order that there may be greater accuracy of operation and resultant econoiny, as well as more satisfactory food.

The annual appropriation for this office is now $\$ 50,000$. The results of its work and a large amount of information gathered from a great variety of sources have been published in scientific journals, Experiment Station Record, Journal of Agricultural Research, technical and popular bulletins of the Department of Agriculture, and the public press, and have been widely disseminated through correspondence and the extension service of the department and the agricultural colleges. 


THIS BOOK IS DUE ON THE LAST DATE STAMPED BELOW

AN INITIAL FINE OF 25 CENTS WILL BE ASSESSED FOR FAILURE TO RETURN THIS BOOK ON THE DATE DUE. THE PENALTY WILL. INCREASE TO 50 CENTS ON THE FOURTH DAY AND TO \$1.00 ON THE SEVENTH DAY OVERDUE.

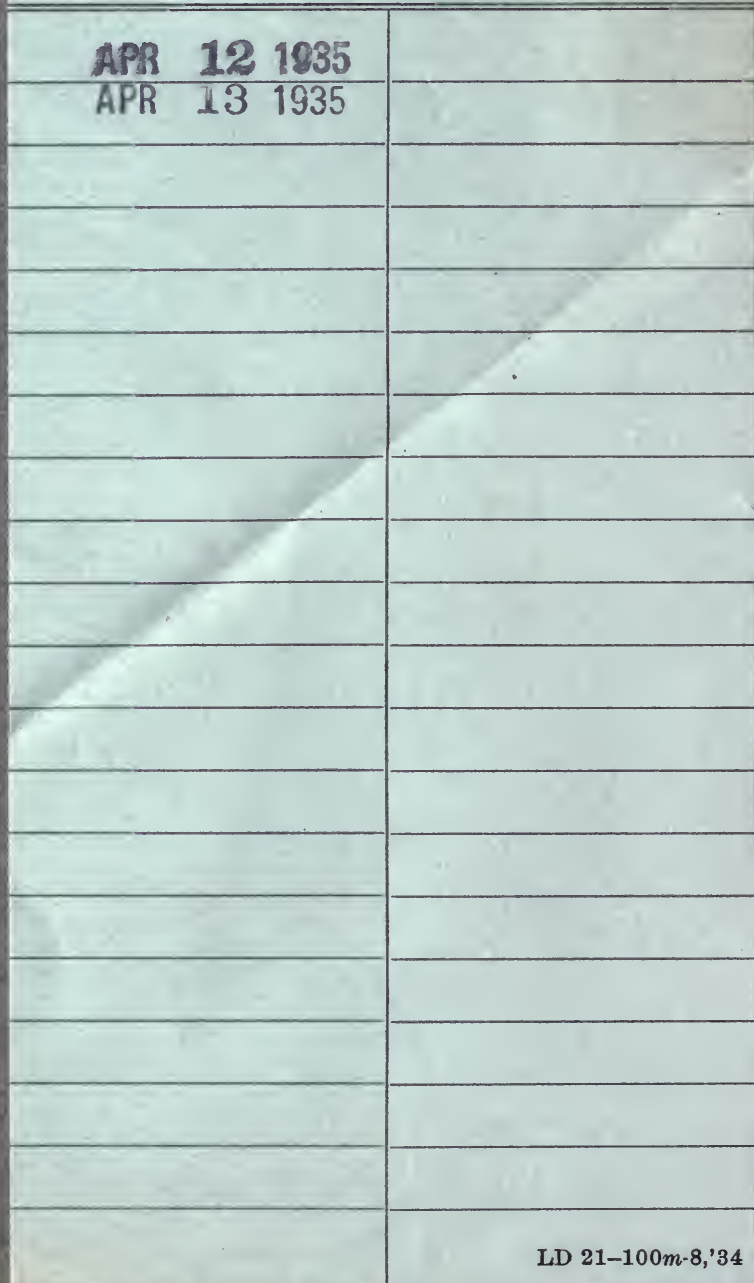


Photomount

Pamphlet

Binder

Gaylord Bros.

Makers

Syracuse, N. Y.

PAT. JAN 21, 1908

\section{8}

UNIVERSITY OF CALIFORNIA LIBRARY 
